\title{
MIMOSOUDNÍ ŘEŠENÍ SPOTŘEBITELSKÝCH SPORŮ ONLINE V PRÁVU EU A JEHO DOPADY NA ČESKOU PRÁVNÍ ÚPRAVU*
}

\author{
PAVEL LOUTOCKÝ**
}

\begin{abstract}
ABSTRAKT
Cílem článku je představit mimosoudního řešení spotřebitelských sporů online $v$ právu Evropské unie s využitím ODR (online dispute resolution) a zhodnotit jeho dopady na českou právní úpravu. Daný způsob řešení sporů by měl poskytovat jednoduché, efektivní, rychlé a levné mimosoudní řě̌ení sporů souvislosti $s$ online transakcemi. Účelem tohoto článku je detailněji prezentovat evropský právní režim a zabývat se jeho jednotlivými fázemi. V druhé části pak budou posouzeny konkrétní dopady představeného právního režimu na českou právní úpravu. V rámci celého článku budou prezentována jednotlivá úskalí, která nepřispívají $k$ celkové efektivitě a využitelnosti prezentovaného právního rámce.
\end{abstract}

\section{ABSTRACT}

The main aim of this article is to introduce online out-of-court consumer dispute settlement in the law of the European union using ODR (Online Dispute Resolution) and to evaluate its impact on the Czech legislation. Presented dispute resolution regime should provide simple, effective, fast and inexpensive out-of-court

Tento článek částečně vychází z LOUTOCKÝ, Pavel. Mimosoudní řešení spotřebitelských sporů online právu EU [online]. Brno, 2017 [cit. 27. 3. 2017]. Rigorózní práce. Masarykova univerzita, Právnická fakulta. Dostupné z: https://is.muni.cz/auth/th/210290/ pravf_r/Rigorozni_prace_Pavel_Loutocky.pdf

** JUDr. Pavel Loutocký, BA (Hons) je prezenčním doktorským studentem na Ústavu práva technologií PrF MU. Kontaktní e-mail: loutocky@mail.muni.cz. 
settlement of the disputes related to the online transactions. The purpose of this article is to present in detail European legal framework and to go through its various phases. The second part will assess specific impacts of introduced legal regime on the Czech legislation. Various difficulties that do not contribute to the overall effectiveness and efficiency of the present legal framework are presented throughout the whole article.

\section{KLÍČOVÁ SLOVA}

online řěsení sporů, ODR, ADR, ODR platforma, spotřebitel, elektronické obchodování, subjekt alternativního řě̌ení sporů, obchodník, směrnice 2013/11/EU o spotřebitelském ADR, nařżení č. 524/2013 o ODR, zákon o ochraně spotrebitele

\section{KEYWORDS}

online dispute resolution, $O D R, A D R, O D R$ platform, consumer, electronic commerce, alternative dispute resolution entity, trader, Directive 2013/11/EU on consumer ADR, Regulation No 524/2013 on ODR, Consumer Protection Act

\section{INICIATIVA EVROPSKÉ UNIE TÝKAJÍCÍ SE ONLINE ŘEŠENÍ SPORŮ}

Odbornou veřejností, ${ }^{1}$ ale i Evropskou uniî́ ${ }^{2}$ bylo opakovaně konstatováno, že roztřriššěnost vnitřního trhu zabraňuje dalšímu rozšíření obchodování (vnitrostátního i přeshraničního) zejména v oblasti spotřebitelských transakcí. Heterogenní dostupnost účinných, rychlých, jednoduchých a levných možností řešení sporů vyplývajících z prodeje zboží a poskytování služeb

\footnotetext{
Např́íklad WEATHERILL, Stephen. EU Consumer Law and Policy. 2. vyd. B.m.: Edward Elgar Publishing, 2013, 253 s. ISBN 9780857936981. S. 25 násl., nebo CORTÉS, Pablo. Online Dispute Resolution for Consumers in the European Union. Oxon: Routldge, 2011, 288 s. ISBN 9780415562072. S. 14-17.

2 ALLEWELDT, Frank, Senda KARA, Nicholas MCSPEDDEN-BROWN, Anna FIELDER, Fabian ZULEEG Agathe OSINSKI. Contribution of the Internal Market and Consumer Protection to Growth. Directorate General for Internal Policies Policy Department A: Economic and Scientific Policy [online]. IP/A/IMCO/2014-04, prosinec 2014 [cit. 27. 3. 2017]. Dostupné z: http://www.europarl.europa.eu/RegData/etudes/STUD/2014/518762/IPOL_STU(2014)51 8762_EN.pdf
} 
ve všech členských státech představuje zásadní překážky v růstu elektronického obchodování, což dále omezuje kvalitu nabízených služeb pro spotřebitele v celé Evropské unii. ${ }^{3}$

„Odhodlání spotréebiteli̊ usilovat o nápravu problematické situace do značné míry závisí na hodnotě sporu. “" Posouzení dopadů návrhu pro ADR a ODR ${ }^{5}$ v EU uvádí, že pokud je sporná hodnota zboží nebo služeb v řádu stovek euro, je vysoce pravděpodobné, že spotřebitel nevyužije soudního řízení díky celkové složitosti soudního procesu, jeho nákladnosti a zdlouhavosti. ${ }^{6}$ Bogdan uvádí, že „rýznamný podíl - asi dvacet procent spotřebitelů - zažilo problémy $v$ souvislosti $s$ přeshraničním nákupem zboží a služeb $v$ rámci $E U$, “7 na čemž má většinový podíl právě oblast elektronického obchodování. $\mathrm{Z}$ toho důvodu jen $18 \%$ spotřebitelů v Evropské unii využilo k přeshraničnímu nakupování internet během roku 2014; v roce 2015 dokonce pak pouze $12 \% .{ }^{8}$ Díky tomu, že jsou dané spory málokdy soudem (či jakkoli jinak) řešeny, dosahuje celková ekonomická ztráta v Evropě

3 Recitál 4. Nařízení Evropského parlamentu a Rady (EU) č. 524/2013 ze dne 21. května 2013 o řešení spotřebitelských sporů on-line a o změně nařízení (ES) č. 2006/2004 a směrnice 2009/22/ES (nařízení o řešení spotřebitelských sporů on-line). In: EUR-Lex [právní informační systém]. Úřad pro publikace Evropské unie [cit. 18. 3. 2017]. Dostupné z: http://eur-lex.europa.eu/legal-content/CS/TXT/?uri=celex:32013R0524 (dále jen „nařízení o ODR").

4 Impact Assessment on Proposal for a Directive of the European Parliament and of the Council on Alternative Dispute Resolution for consumer disputes (Directive on consumer ADR) and Proposal for a Regulation of the European Parliament and of the Council on Online Dispute Resolution for consumer disputes (Regulation on consumer ODR) [online]. SEC(2011) 1408 final [cit. 27. 3. 2017]. Dostupné z: http://ec.europa.eu/consumers/archive/redress_cons/docs/ impact_assessment_adr_en.pdf (dále jen „posouzení dopadů návrhu pro ADR a ODR v EU“). S. 5.

5 K samotnému pojmu ODR potom více viz např.: HÖRNLE, Julia. Cross - border Internet Dispute Resolution. Cambridge: Cambridge University Press, 2009, 320 s. ISBN 9780521896207. S. 48, POLČÁK, Radim. Internet a proměny práva. 1. vyd. Praha: Auditorium, 2012, 388 s. edice Téma. ISBN 9788087284223. S. 266-267 nebo LOUTOCKÝ, Pavel. Slabiny a silné stránky online rozhodčího řízení se zaměřením na B2B transakce. Revue pro právo a technologie, Brno: Masarykova univerzita, 2012, roč. 3, č. 6, s. 76-111. ISSN 18045383. S. 80-81.

6 Posouzení dopadů návrhu pro ADR a ODR v EU. S. 20.

7 BOGDAN, Michael. The New EU Regulation on Online Resolution for Consumer Disputes. Masaryk University Journal for Law and Technology, roč. 9, č. 1, 2015, s. 155-163. ISSN 18025943. S. 155. 
0,4 \% HDP (sic!). ${ }^{9}$ Jak ale vyplývá z průzkumu Evropské komise, větší počet obyvatel EU má zájem řešit spory mimosoudně, ${ }^{10}$ a to díky časové frustraci a neekonomičnosti při řešení sporu soudní cestou. ${ }^{11}$ Stejně tak valná většina obchodníků dává přednost urovnání daných sporů mimosoudní cestou před jejich řešením u soudu. ${ }^{12}$

$\mathrm{Z}$ uvedeného lze vyvozovat, že alternativní způsoby řešení sporů s využitím moderních technologií jsou vhodným a chtěným řešením pro stávající nevyhovující situaci, kdy tradiční soudní mechanismy nedokáží reagovat na vysoký počet jednoduchých sporů a neposkytují tak adekvátní nástroje pro jejich řešení. Evropská komise se daného potenciálu pokusila využít a nabídla řešení $\mathrm{v}$ podobě směrnice o spotřebitelském $\mathrm{ADR}^{13}$ a nařízení o ODR. Očekávání efektivního urovnání jednoduchých sporů, které ODR generálně nabízí, totiž nebylo zejména na území Evropy prozatím př́iliš naplněno. ${ }^{14}$ Evropský právní rámec byl vyvinut pro řešení sporů ve spotřebitelských sporech, které vyplývají z prodeje zboží nebo poskytování služeb mezi evropskými spotřebiteli a obchodníky EU. Hlavním cílem evropské právní úpravy je zejména snaha nabídnout spotřebiteli dostupný a efektivní nástroj pro řešení sporů z elektronického obchodování a podpořit tak zej-

8 Consumer attitudes towards cross-border trade and consumer protection. Conducted by TNS Political \& Social at the request of the European Commission, Directorate-General for Health and Consumers [online]. European Commission. Public Opinion. Flash Eurobarometer 397. September 2015 [cit. 27. 3. 2017]. Dostupné z: http://ec.europa.eu/COMMFrontOffice/PublicOpinion/index.cfm/Survey/getSurveyDetail/instruments/FLASH/surveyKy/2031 (dále jen „Eurobarometr 2015“). S. 8.

9 Posouzení dopadů návrhu pro ADR a ODR v EU. S. 5.

10 Eurobarometr 2015. S. 18.

${ }^{11}$ Z nejaktuálněji dostupné studie Rady Evropy např́íklad vyplývá, že v Itálii trvala v roce 2012 délka řízení u soudu prvního stupně průměrně 707 dní, zatímco v České republice 155 dní. Pro komplexní informace týkající se problematiky soudnictví v členských státech Rady Evropy více viz Report on „European judicial systems - Edition 2014 (2012 data): efficiency and quality of justice" [online]. Council of Europe [cit. 27. 3. 2017]. Dostupné z: http://www.coe.int/t/dghl/cooperation/cepej/evaluation/2014/Rapport_2014_en.pdf

12 Posouzení dopadů návrhu pro ADR a ODR v EU. S. 13.

${ }^{13}$ Směrnice Evropského parlamentu a Rady 2013/11/EU ze dne 21. května 2013 o alternativním řešení spotřebitelských sporů a o změně nařízení (ES) č. 2006/2004 a směrnice 2009/22/ES (směrnice o alternativním řešení spotřebitelských sporů). In: EUR-Lex [právní informační systém]. Úřad pro publikace Evropské unie [cit. 24. 3. 2017]. Dostupné z: http://eur-lex.europa.eu/legal-content/CS/ALL/?uri =CELEX:32013L0011 (dále jen „směrnice o spotřebitelském ADR“). 
ména přeshraniční růst takovýchto transakcí. Účelem „tohoto harmonizačního opatření by tak mělo být vyplnění mezery v př̌stupu ke spravedlnosti.“15

\section{1 ÚVAHY EVROPSKÉ UNIE PŘEDCHÁZEJÍCÍ VYTVOŘENÍ REŽIMU PRO (ONLINE) MIMOSOUDNÍ ŘEŠENÍ SPORŮ}

Obecný nedostatek adekvátních mechanismů, které by sloužily $\mathrm{k}$ řešení sporů vyplývajících z elektronického obchodování, má neblahý vliv na tuto oblast. Již v roce 2000 tak bylo jedním z požadavků směrnice o elektronickém obchodu ${ }^{16}$ podpořit zejména využití ODR a vhodně harmonizovat právní řády členských států. Recitál 51 směrnice o elektronickém obchodu tak zdůrazñuje, že „každý členský stát je $v$ př́padě potřeby povinen změnit vnitrostátní predpisy, které by mohly ohrozit využívání způsobů mimosoudního urovnávání sporů elektronickou cestou. Tato změna musí umožnit právně a fakticky skutečné a účinné fungování těchto způsobů včetně přeshraničních případů."

Směrnice o elektronickém obchodu v tomto vycházela částečně $\mathrm{z}$ úvah vyplývajících ze Zelené knihy z roku 1993 zabývající se př́stupem spotřebitele ke spravedlnosti ${ }^{17}$ a $\mathrm{z}$ doporučení Evropské komise $\mathrm{z}$ roku $1998,{ }^{18}$ které obecně položily základ úvahám o mimosoudním řešení sporů online.

${ }^{14}$ CORTÉS, Pablo. European Union's initiatives on ADR and ODR. Computer and Telecommunications Law Review, London: Sweet \& Maxwell, 2015, roč. 21, č. 8, 2015, s. 257-266. ISSN 13573128. S. 257, nebo CORTÉS, Pablo, Arno R. LODDER. Consumer Dispute Resolution Goes Online: Reflections on the Evolution of European Law for Out-of-Court Redress. Maastricht Journal of European and Comparative Law, 2014, roč. 21, č. 1, s. 14-38. ISSN 1023263X. S. 30.

15 CREUTZFELDT, Naomi J. Implementation of the Consumer ADR Directive [online]. Prijato k publikaci v Journal of European Consumer and Market Law, no. 1-2016 [cit. 24. 3. 2017]. Dostupné z: http://ssrn.com/abstract $=2729208$. S. 2.

16 Směrnice Evropského parlamentu a Rady 2000/31/ES ze dne 8. června 2000 o některých právních aspektech služeb informační společnosti, zejména elektronického obchodu, na vnitřním trhu (směrnice o elektronickém obchodu). In: EUR-Lex [právní informační systém]. Úřad pro publikace Evropské unie [cit. 24. 3. 2017]. Dostupné z: http://eur-lex.europa.eu/legal-content/CS/TXT/?qid $=1463124717882 \& u r i=$ CELEX:32000L0031 (dále je „směrnice o elektronickém obchodu“).

17 Commission Green Paper of 16 November 1993 on access of consumers to justice and the settlement of consumer disputes in the single market. In: EUR-Lex [právní informační systém]. Úřad pro publikace Evropské unie [cit. 13. 3. 2017]. Dostupné z: http://eur-lex.europa.eu/legal-content/EN/TXT/HTML/?uri = URISERV:132023\&from $=$ CS 
Zmínka o možné asistenci technologií v takovém procesu se ale objevuje oficiálně až ve výše citovaném Recitálu 51 směrnice o elektronickém obchodu. Společně s doporučením Evropské komise z roku $2001^{19}$ aktivita $\mathrm{v}$ dané oblasti vyústila $\mathrm{v}$ harmonizaci mediace $\mathrm{v}$ civilních a obchodních vě$\operatorname{cech}^{20}$ a v zakotvení řízení o drobných nárocích do nařízení. ${ }^{21}$ „Oba tyto předpisy poskytují prostředí, které napomohlo rozvoji a prỉietí ODR řešení $[\ldots] .{ }^{“ 22}$

Nelze ale opomenout vybrané instituce, které svou činností rovněž inspirovaly vývoj mimosoudního řešení sporů včetně využití metod ODR. Evropská mimosoudní sít (European Extra-Judicial Network, dále jen „EEJ-Net“) jako první v roce 2001 nabídla v jednotlivých státech kontaktní místa, na která se spotřebitel mohl obrátit v otázkách mimosoudního urovnání sporů $\mathrm{s}$ využitím internetu (aby tak bylo možno předcházet komplikacím, které vznikají z roztřišstěnosti právních řádů jednotlivých členských států). EEJNet tak fungovala zejména jako zprostředkovatel informací mezi stranami

${ }^{18}$ Commission Recommendation of 30 March 1998 on the principles applicable to the bodies responsible for out-of-court settlement of consumer disputes (Text with EEA relevance) (98/257/EC). In: EUR-Lex [právní informační systém]. Úřad pro publikace Evropské unie [cit. 27. 3. 2017]. Dostupné z: http://eur-lex.europa.eu/legal-content/EN/TXT/HTML/? uri $=$ CELEX:31998H0257\&from $=$ CS

19 Commission Recommendation of 4 April 2001 on the principles for out-of-court bodies involved in the consensual resolution of consumer disputes (notified under document number C(2001) 1016) (Text with EEA relevance) (2001/310/EC). In: EUR-Lex [právní informační systém]. Úřad pro publikace Evropské unie [cit. 27. 3. 2017]. Dostupné z: http://eurlex.europa.eu/LexUriServ/LexUriServ.do?uri = CELEX:32001H0310:EN:HTML

${ }^{20}$ Směrnice Evropského parlamentu a Rady 2008/52/ES ze dne 21. května 2008 o některých aspektech mediace $\mathrm{v}$ občanských a obchodních věcech. In: EUR-Lex [právní informační systém]. Úřad pro publikace Evropské unie [cit. 13. 3. 2017]. Dostupné z: http://eur-lex.europa.eu/legal-content/CS/TXT/?qid = 1463132713289\&uri $=$ CELEX:32008L0052

${ }^{21}$ Nařízení počítá s využitím moderních technologií, když explicitně stanovuje, že „soud může vést ústní jednání prostřednictvím videokonference nebo pomocí jiných komunikačních technologií, pokud jsou k dispozici nezbytné technické prostředky. “ Článek 8 (obdobně recitál 20). Nařízení Evropského parlamentu a Rady (ES) č. 861/2007 ze dne 11. července 2007, kterým se zavádí evropské řízení o drobných nárocích. In: EUR-Lex [právní informační systém]. Úřad pro publikace Evropské unie [cit. 29. 3. 2017]. Dostupné z: http://eurlex.europa.eu/legal-content/CS/TXT/?uri = CELEX\%3A32007R0861

22 POBLET, Marta, Graham ROSS. ODR in Europe. In: WAHAB, Mohamed S. Abdel, Ethan KATSH, Daniel RAINEY. Online Dispute Resolution: Theory and Practice: A Treatise on Technology and Dispute Resolution. The Hague: Eleven International Publishing, 2012, s. 453-471. ISBN 9789490947255. S. 456. 
a jako neoficiální mediátor (anglicky lze EEJ-Net označit $\mathrm{v}$ širším slova smyslu jako clearing house). Tato sít se společně s institucí Euroguichets přetvořila v roce $2006 \mathrm{v}$ sít Evropských spotřebitelských center (anglicky $\mathrm{Eu}$ ropean Consumers Centres network, dále jen „ECC-Net") ${ }^{23}$ která prostřednictvím národních kontaktních míst poskytuje spotřebitelům asistenci při řešení přeshraničních sporů, které vznikly z koupě zboží či poskytování služeb. Jako další evropský projekt, který výrazně přispěl k současné implementaci ODR režimu a sloužil pro řešení spotřebitelských sporů, lze uvést Electronic Consumer Dispute Resoltuion (ECODIR), který byl zaměřen striktně na online transakce. V rámci tohoto pilotního projektu funkčního mezi lety 2001 a $2003^{24}$ se podařilo vyřešit jen přibližně 200 sporů v hodnotě do 350 eur, nicméně zkušenosti v rámci tohoto experimentu nabyté posloužily pro další vývoj $A D R$ a ODR režimu v rámci EU. ${ }^{25}$ Výše zmíněné tak zásadním způsobem přispělo $\mathrm{k}$ aktuální podobě evropské právní úpravy mimosoudního řešení spotřebitelských sporů s využitím ODR.

\section{PRÁVNÍ REŽIM ADR A ODR V EU}

Cortés a Lodder uvádí tři aspekty, které brání dalšímu rozvoji zejména v oblasti ODR a které by bylo žádoucí aktuálním režimem pro ADR a ODR v Evropské unii překonat. První překážkou je obecný nedostatek povědomí o ODR a často komplikovaný přístup $\mathrm{k}$ němu. Spotřebitele ${ }^{26}$ a obchodníci ${ }^{27}$ tak mnohdy neví, co od něj mohou očekávat, což obecně snižuje důvěru $\mathrm{v}$ takové řešení. Cortés a Lodder vidí problém také $\mathrm{v}$ tom, že ODR není dostatečně zakotveno $\mathrm{v}$ rámci právního systému, což by posílilo jeho pozici.

${ }^{23}$ European Consumers Centres [online]. European Comission [cit. 22. 3. 2017]. Dostupné z: http://ec.europa.eu/consumers/solving_consumer_disputes/non-judicial_redress/ecc-net/index_en.htm

${ }^{24}$ ECODIR je v současné chvíli stále funkční, nicméně je soukromoprávním subjektem. ECODIR [online]. Electronic Consumer Dispute Resolution [cit. 22. 3. 2017]. Dostupný z: http://www.ecodir.org/

${ }^{25}$ O dalších iniciativách více viz POBLET, Marta, Graham ROSS. ODR in Europe. In: WAHAB, Mohamed S. Abdel, Ethan KATSH, Daniel RAINEY. Online Dispute Resolution: Theory and Practice: Treatise on Technology and Dispute Resolution. The Hague: Eleven International Publishing, 2012, s. 453-471. ISBN 9789490947255. S. 457 a násl. 
Poslední překážkou je pak motivace stran. ${ }^{28}$ Nadto je třeba ještě uvést zásadní požadavek nezbytný pro funkční a využitelný režim ODR, a to nutnost poskytnout jednoduché a přehledné řešení.

Cílem této kapitoly je zejména představit právní režim zavedený směrnicí o spotřebitelském ADR a nařízením o ODR. Na to pak navážeme představením konkrétního postupu při řešení spotřebitelského sporu online rámci evropského právního režimu.

\subsection{SMĚRNICE O SPOTŘEBITELSKÉM ADR}

Jedním $\mathrm{z}$ fundamentálních problémů mimosoudního řešení sporů v Evropské unii je rozdílnost ADR mechanismů v jednotlivých členských státech. Navíc jen v některých má delší tradici (zejména ve státech západní Evropy a v severských státech). ${ }^{29}$ Právě směrnice o spotřebitelském ADR si klade za cíl integrovat systém alternativního řešení sporů tak, aby byl vnitrostátně i přeshraničně přístupný po celé Evropě, a podpořit substantivně ochranu

${ }^{26}$ Spotřebitel je v souvislosti s evropským režimem ADR / ODR definován jako ,fyzická osoba, jež jedná za účelem, který nelze považovat za provozování jejîho obchodu, živnosti nebo řemesla anebo výkonu jejího povolání.“ Článek 4 odst. 1 písm. a). Směrnice o spotřebitelském ADR. K definici spotřebitele dále více viz CORTÉS, Pablo. Online Dispute Resolution for Consumers in the European Union. Oxon: Routldge, 2011, 288 s. ISBN 9780415562072. S. 10 a násl.

${ }^{27}$ Obchodník je pak definován jako „fyzická nebo právnická osoba, bez ohledu na to, zda je v soukromém nebo veřejném vlastnictví, jež jedná, včetně jednání jakékoli osoby jednající jejím jménem nebo z jejího pověřní, za účelem souvisejícím s jejím obchodem, živností nebo řemeslem anebo výkonem jejího svobodného povolání.“ Článek 4 odst. 1 písm. b). Směrnice o spotřebitelském ADR.

28 CORTÉS, Pablo, Arno R. LODDER. Consumer Dispute Resolution Goes Online: Reflections on the Evolution of European Law for Out-of-Court Redress. Maastricht Journal of European and Comparative Law, 2014, roč. 21, č. 1, s. 14-38. ISSN 1023263X. S. 22-24.

29 Podrobnému výkladu v otázkách tradice mimosoudního řešení spotřebitelských sporů v Belgii, Francii, Německu, Nizozemsku, Švédsku a Spojeném království se postupně věnuje Voet, Hodges, Benhör, Creutzfeldt-Banda a Weber v HODGES, Christopher J., Iris BENÖHR a Naomi CREUTZFELDT-BANDA. Consumer ADR in Europe: Civil Justice Systems. Oxford: Hart publishing, 2012, 503 s. ISBN 9781849463485. S. 25-117, 129-167, 229-339. Všem členským státům se pak v rámci studie věnuje COLE, Tony, Ilias BANTEKAS, Federico FERRETTI, Christine RIEFA, Barbara WARWAS a Pietro ORTOLANI. Legal Instruments and Practice of Arbitration in the EU, Study [online]. Directorate General for Internal Policies Policy Department C: Citizens' Rights and Constitutional Affairs, 2014 [cit. 23. 3. 2017]. Dostupné z: http://www.europarl.europa.eu/RegData/etudes/STUD/2015/509988/IPOL _STU(2015)509988_EN.pdf 
spotřebitele v této oblasti. Hlavním smyslem směrnice je „zajištění prǐstupu $k$ jednoduchým, efektivním, rychlým a levným způsobům řešení vnitrostátních i preshraničních sporů, které se vyskytnou $v$ souvislosti s kupními smlouvami nebo se smlouvami o poskytování služeb, by mělo přinést prospěch spotřebitelům, a posílit tak jejich důvěru $v$ trh. Tento př́stup by se měl vztahovat na transakce uskutečněné on-line i off-line a má velký význam zejména $v$ př́padě, že spotřebitelé nakupují $v$ zahraniči. “ ${ }^{30}$

Mimosoudní řešení sporů, které bylo různými subjekty nabízeno spotřebiteli před představením směrnice o spotřebitelském ADR, bylo často omezeno geograficky, nebylo dostupné ve všech členských státech a mnohdy bylo zaměřeno jen na některé oblasti sporů. ${ }^{31}$ Směrnice tak měla poskytnout obecný právní rámec $\mathrm{k}$ vytvoření vhodného a funkčního celoevropského režimu pro spotřebitelské ADR. Nečiní tak ovšem prostřednictvím navržení souboru procesních pravidel, která by byla přímo využita poskytovateli ADR či ODR (tak, jak v případě ODR činí Working Group III), ${ }^{32}$ ale stanovuje hlavní právní zásady, které jsou implementovány do jednotlivých právních řádů členských států. Směrnice o spotřebitelském ADR proto stanovuje minimální standardy a „nestojí $v$ cestě pro zakotvení vy̌šího standardu ochrany spotřebitele. ${ }^{\text {333 }}$ Stanovuje zejména nutnost zajistit přístup

${ }^{30}$ Recitál 4. Směrnice o spotřebitelském ADR.

${ }^{31}$ HÖRNLE, Julia. Encouraging Online Dispute Resolution in the EU and Beyond-Keeping Costs Low or Standards High? European Law Review, London: Sweet \& Maxwell, 2013, roč. 38, s. 187-208. ISSN 03075400. S. 195.

${ }^{32}$ Návrh článku B. Draft Preamble odst. 1. Online dispute resolution for cross-border electronic commerce transactions: draft procedural rules [online]. Working Group III (Online Dispute Resolution). United Nations Commission on International Trade Law (UCITRAL). Thirty first session. New York, 9-13 February 2015, A/CN.9/WG.III/WP.133 [cit. 22. 3. 2017]. Dostupné z: https://documents-dds-ny.un.org/doc/UNDOC/LTD/V14/080/65/PDF/ V1408065.pdf?OpenElement. S. 4, nebo HÖRNLE, Julia. Encouraging Online Dispute Resolution in the EU and Beyond-Keeping Costs Low or Standards High? European Law Review, London: Sweet \& Maxwell, 2013, roč. 38, s. 187-208. ISSN 03075400. S. 189. Ke sbližování činnosti Working Group III a evropského režimu ODR pak více viz CORTÉS, Pablo, Esteban DE LA ROSA. Building a global redress system for low-value cross-border disputes. International \& Comparative Law quaterly, Cambridge: Cambridge University Press, 2013, roč. 62, č. 2, s. 407-440. ISSN 00205893. S. 425-438.

33 BOGDAN, Michael. The New EU Regulation on Online Resolution for Consumer Disputes. Masaryk University Journal for Law and Technology, roč. 9, č. 1, 2015, s. 155-163. ISSN 18025943. S. 157. 
k subjektům a postupům alternativního řešení sporů, ${ }^{34}$ odbornost, nezávislost a nestrannost osoby, která se na rozhodování sporu podílí, ${ }^{35}$ transparentnost poskytovaného řešení, ${ }^{36}$ spravedlnost, ${ }^{37}$ volnost (dobrovolnost účasti na celém režimu) ${ }^{38}$ a efektivitu daného postupu ${ }^{39}$ a jeho zákonnost ${ }^{40}$ v rámci právních řádů jednotlivých členských států. ${ }^{41}$

Smyslem těchto principů je tak zajistit důvěru spotřebitele v konkrétního poskytovatele alternativního řešení sporů, a tedy $\mathrm{v}$ mimosoudní řešení jako celek v souvislosti s elektronickým obchodováním. ${ }^{42}$ Členské státy musí zajistit, aby vybraní poskytovatelé ADR nabízeli své služby v souladu se standardy stanovenými ve směrnici o spotřebitelském ADR, respektive aby jejich procesní postupy byly uvedeny $\mathrm{v}$ soulad s principy, které směrnice o spotřebitelském ADR požaduje. Takto specifikovaný a aprobovaný poskytovatel mimosoudního řešení sporů je ve směrnici definován jako subjekt alternativního řešení sporů (anglicky uváděn jako $A D R$ entity, dále rovněž jako „subjekt ADR“), ${ }^{43}$ který může nabízet nezávazné (negociace, mediace, konciliace) závazné (rozhodčí řízení) mimosoudní řešení sporů. ${ }^{44}$

34 Článek 5. Směrnice o spotřebitelském ADR.

35 Článek 6. Směrnice o spotřebitelském ADR.

36 Článek 7. Směrnice o spotřebitelském ADR.

37 Článek 9. Směrnice o spotřebitelském ADR.

38 Článek 10. Směrnice o spotřebitelském ADR.

39 Článek 8. Směrnice o spotřebitelském ADR.

40 Článek 11. Směrnice o spotřebitelském ADR.

${ }^{41}$ K jednotlivým principům viz více např́klad CORTÉS, Pablo. European Union's initiatives on ADR and ODR. Computer and Telecommunications Law Review, London: Sweet \& Maxwell, 2015, roč. 21, č. 8, 2015, s. 257-266. ISSN 13573128. S. 259-264.

42 Recitál 9. Směrnice o spotřebitelském ADR.

43 Subjektem alternativního řešení sporů se myslí „subjekt, at už je jeho název jakýkoli, který je trvale usazen, a nabizí řešení sporů prostřednictvím postupu alternativního řešení sporů a je uveden na seznamu podle čl. 20 odst. 2." Článek 4 odst. 1 písm. h). Směrnice o spotřebitelském ADR.

Subjekt alternativního řešení sporů se musí především dostatečně identifikovat (uvést svůj název, internetovou adresu, apod.), musí uvést, jestli za své služby vybírá poplatky (může poskytovat své služby i zdarma), dále pak jazyk (jazyky) řízení, kategorie sporů, které řeší, je-li nutná fyzická přítomnost stran a jaký druh rozhodnutí poskytuje (nezávazné či závazné rozhodování). Článek 20 odst. 2 . Směrnice o spotřebitelském ADR. 
Každý členský stát pak musí určit příslušný orgán (anglicky competent authority), ${ }^{45}$ který posoudí kvalitu služeb poskytovaných subjektem alternativního řešení sporů a to, zda jsou naplněny všechny požadavky na takový subjekt kladené směrnicí o spotřebitelském ADR a vnitrostátními právními předpisy, které směrnici implementují. $\mathrm{V}$ případě, že konkrétní subjekt požadavky kladené takovýmto právním rámcem přestane splňovat, př́islušný orgán se pokusí sjednat nápravu. Pokud k ní nedojde ani do tří měsíců, orgán takovýto subjekt ze seznamu vyškrtne. ${ }^{46} \mathrm{O}$ subjektech a jednotlivých změnách pak vždy neprodleně informuje Evropskou komisi. ${ }^{47}$

Jak uvádí na svých stránkách Evropská komise, „př̌stup spotřebitele $k$ ADR je zajištěn bez ohledu na to, jaký výrobek nebo službu si zakoupil (z režimu směrnice spotřebitelském ADR je ovšem vyloučena oblast související se zdravotními službami či s poskytováním vysokoškolského vzdēlání), ${ }^{48}$ zda výrobek nebo služba byla pořżzena online nebo offline a zda je obchodník usazen $v$ členském státě spotřebitele či v jiném členském státě.“49

${ }^{44}$ Subjekty alternativního řešení sporů v České republice jsou Český telekomunikační úřad, Energetický regulační úřad, Finanční arbitr, Česká obchodní inspekce, Česká advokátní komora a Sdružení českých spotřebitelů, z.ú. Seznam subjektů mimosoudního řešení spotřebitelských sporů [online]. Ministerstvo průmyslu a obchodu [cit. 14. 3. 2017]. Dostupné z: http://www.mpo.cz/dokument171389.html

45 Příslušným orgánem v České republice je Ministerstvo průmyslu a obchodu. Pro srovnání uvádíme, že ve Spojeném království je to z pověrení vlády nezisková organizace Chartered Trading Standards Institute. Ta ale není jediným př́slušným orgánem (ve specifických oblastech jsou to například Gambling Commission, Civil Aviation Authority nebo Office of Communications). Na základě článku 18 směrnice o spotřebitelském ADR ale Chartered Trading Standards Insitiute slouží jako jednotné kontaktní místo pro Komisi. O tom více $\mathrm{Al}$ ternative Dispute Resolution (ADR) [online]. Chartered Trading Standards Insitiute [cit. 14. 3. 2017]. Dostupné z: http://www.tradingstandards.uk/advice/AlternativeDisputeResolution.cfm

${ }^{46}$ Článek 20. Směrnice o spotřebitelském ADR.

47 Zarážející ovšem je, že přestože v článku 18 odst. 2 je stanoveno, že "Komise vypracuje seznam př́slušných orgánů, př́padně včetně jednotného kontaktního místa, [...] a tento seznam zveřejní $v$ Úředním věstníku Evropské unie“, nebyl prozatím v Úředním věstníku takový seznam zveřejněn, což nepříznivě ovlivňuje důvěru v celý systém ADR a ODR v rámci Evropské unie.

${ }^{48}$ Oblastmi, na které se směrnice o spotřebitelském ADR nevztahuje, jsou dále např́íklad postupy zahájené obchodníkem vǔči spotřebiteli, spory mezi obchodníky, přímé jednání mezi spotřebitelem a obchodníkem či pokusy soudce o urovnání sporu během soudního řízení. Článek 2. Směrnice o spotřebitelském ADR. 
Členským státům bylo uloženo, aby implementovaly směrnici o spotřebitelském ADR do 9. července 2015. V České republice byla směrnice ovšem implementována zákonem č. 378/2015 Sb., kterým se mění zákon č. 634/1992 Sb., o ochraně spotřebitele, ve znění pozdějších předpisů, a některé další zákony (dále jen „novela ZOS“) až s účinností k 28. prosinci 2015, tedy téměř s půlročním zpožděním.

\subsection{NAŘÍZENÍ O ODR (ODR PLATFORMA)}

Směrnice o spotřebitelském ADR a nařízení o ODR jsou dva vzájemně propojené legislativní nástroje a nařízení o ODR musí být aplikováno v souladu se směrnicí. Role nařízení o ODR je v podstatě jediná:

„Nařízení (EU)č. 524/2013 stanoví zř̌zení platformy pro řešení sporů online, která spotřebitelům a obchodníkům nabízí jednotné kontaktní místo pro mimosoudní řešení sporů on-line prostřednictvím subjekti̊ alternativního řěsení sporů, které jsou s platformou spojeny a nabizzejí alternativní řešení sporů prostréednictvím kvalitních postupů alternativního řešení sporů (dále jen „ODR platforma“). Předpokladem řádného fungování platformy pro řešení sporů online je tudíz dostupnost kvalitních subjektů alternativního řešení sporů v celé Unii. “50

Zř́ízení samotné ODR platformy ${ }^{51}$ je upraveno primárně článkem 5 nař́zení o ODR:

„Platforma pro řešení sporů on-line je jednotným místem, na které se mohou obrátit spotřebitelé a obchodníci usilující o mimosoudní řešení sporů, na něž se vztahuje toto nař́zení. Jedná se o interaktivní internetovou stránku, která umožňuje elektronický a bezplatný př̌stup ve všech úredních jazycích orgánů Unie. “52

\footnotetext{
49 Alternative and Online Dispute Resolution (ADR/ODR) [online]. European Commission [cit. 27. 3. 2017]. Dostupné z: http://ec.europa.eu/consumers/solving_consumer_disputes/nonjudicial_redress/adr-odr/index_en.htm

50 Recitál 12. Směrnice o spotřebitelském ADR.

51 ODR platforma je dostupná zde: Úvodní stránka - řě̌ení sporů online [online]. Evropská komise [cit. 27. 3. 2017]. Dostupné z: https://webgate.ec.europa.eu/odr/

52 Článek 5 odst. 2. Nařízení o ODR.
} 
ODR platforma nabízí možnost řešit spor mezi spotřebitelem a obchodníkem mimosoudně prostřednictvím interaktivní internetové stránky, která účastníkům slouží jako jednotný přístupový bod. ${ }^{53}$ Oblast působnosti je omezena na spory, které vyplývají z kupní smlouvy nebo ze smlouvy o poskytování služeb uzavřené online. ${ }^{54}$ ODR platforma je tak omezena jen na řešení sporů, které vyplývají z online transakcí. ${ }^{55}$ Hörnle pak zjednodušeně uvádí, že hlavní záměr nařízení o ODR je „umožnit spotřebiteli z členského státu A podat stížnost proti obchodníkovi $v$ členském státě $B$ online. “56 ODR platforma tak propojuje spotřebitele s obchodníky a případně s dohodnutým subjektem alternativního řešení sporů. To de facto znamená, že ODR platforma se snaží zjednodušit komunikaci a automatizovat činnost, kterou prozatím prováděla sít spotřebitelských center ECC-Net.

ODR platforma nabízí spotřebiteli online formulář pro podání stížnosti, „informuje respondenta (obchodníka) o podané stížnosti (pozn. autor: a tuto stížnost případně překládá do jazyka obchodníka), asistuje stranám při určení př́slušného subjektu alternativního řešení sporů a předá stížnost dohodnutému subjektu; $k$ tomu všemu lze využít nástroje pro elektronickou správu případů. “57 Poté předá přeloženou stížnost obchodníkovi, nabídne případně seznam subjektů alternativního řešení sporů, asistuje s jejich výběrem a subjektu ADR nabídne možnost bezplatně využít nástroj elektronické správy případů. ${ }^{58}$

Samotný vzhled ODR platformy a její fungování je upraven prováděcím nařízením k ODR platformě. ${ }^{59}$ Jsou tak stanoveny náležitosti elektronického formuláře, informování odpo̊rce ODR platformou, určení subjektu ADR,

53 Definice toho, co ODR znamená, však v nařízení zcela chybí.

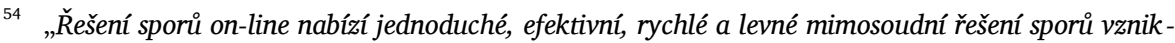
lých v souvislosti s transakcemi prováděnými on-line." Recitál 8. Nařízení o ODR.

55 Článek 2 odst. 1. Nařízení o ODR.

56 HÖRNLE, Julia. Encouraging Online Dispute Resolution in the EU and Beyond-Keeping Costs Low or Standards High? European Law Review, London: Sweet \& Maxwell, 2013, roč. 38, s. 187-208. ISSN 03075400. S. 195.

57 KRAMER, Xandra E. A European Perspective on E-Justice and New Procedural Models: Transforming the Face of Cross-Border Civil Litigation and Adjudication in the EU [online]. Working paper (2015), November 1, 2015 [cit. 27. 3. 2017]. Dostupné z: http://papers.ssrn.com/sol3/papers.cfm?abstract_id=2696978. S. 11.

58 Článek 5 odst. 4 písm. d). Nařízení o ODR. 
informace, jež mají poskytovat subjekty alternativního řešení sporů, ukončení některých sporů a vymazání osobních údajů, systém poskytování zpětné vazby či spolupráce mezi kontaktními místy pro řešení sporů onli$n e^{60}$

Nařízení o ODR rovněž stanovuje kontrolní mechanismy a možnost využití asistence národních kontaktních míst. ${ }^{61}$ Tato kontaktní místa pro řešení sporů online $e^{62}$ by měla podporovat strany sporu $\mathrm{v}$ jejich řešení, tedy asistovat jim při podání stížnosti, předat obecné informace související s ochranou spotřebitele, poskytnout informace o fungování ODR platformy a zejména vysvětlit proces při řešení sporu pomocí subjektů alternativního řešení sporů. ${ }^{63}$ Kontaktní místa však stranám neposkytují samotný nástroj pro řešení sporů. ${ }^{64}$

Nařízení o ODR dále zdůrazňuje, ${ }^{65}$ že podání stížnosti, její postoupení a jakékoli další nakládání (i subjektem alternativního řešení sporů) $s$ informacemi, které jsou ve stížnosti obsaženy, po celou dobu podléhá pravidlům

59 Prováděcí nařízení Komise (EU) 2015/1051 ze dne 1. července 2015 o způsobech provádění funkcí platformy pro řešení sporů on-line, o podrobnostech týkajících se elektronického formuláře pro podávání stížností a o pravidlech týkajících se spolupráce mezi kontaktními místy uvedených v nařízení Evropského parlamentu a Rady (EU) č. 524/2013 o řešení spotřebitelských sporů on-line. In: EUR-Lex [právní informační systém]. Úřad pro publikace Evropské unie [cit. 22. 3. 2017]. Dostupné z: http://eur-lex.europa.eu/legalcontent/CS/TXT/?qid = 1463836823937\&uri = CELEX\%3A32015R1051 (dále jen „prováděcí nařízení k ODR platformě“).

${ }^{60}$ Článek 2-9. Prováděcí nařízení k ODR platformě.

${ }^{61}$ Článek 7. Nařízení o ODR.

${ }^{62}$ Těmito kontaktními místy jsou jednotlivá spotřebitelská centra v rámci sítě ECC-Net nebo národní spotřebitelské organizace. Seznam kontaktních míst je možno nalézt zde: Obratte se na vnitrostátní kontaktní místo [online]. Řešení sporů online [cit. 22. 3. 2017]. Dostupné z: https://webgate.ec.europa.eu/odr/main/?event = main.complaints.odrList

${ }^{63}$ Recitál 25. Nařízení o ODR.

${ }^{64}$ Vhodnější by ale bylo, aby kontaktní místa případně poskytovala prostor pro samotné vyjednávání proto, že jsou se stranami sporu v úzkém kontaktu. To je vhodné zejména kvưli tomu, že při přeshraničním řešení sporu jsou právě centra v rámci sítě ECC-Net spotřebitelskými organizacemi prozatím primárně doporučována k řešení sporu (nikoli tedy ODR platforma). Shodně CORTÉS, Pablo. A New Regulatory Framework for Extra-judicial Consumer Redress: Where We Are and How to Move Forward. Legal Studies, 2015, roč. 35, č. 1, s. 114-141. ISSN 1748-121X. S. 122.

${ }^{65}$ Recitál 27, 29 článek 13. Nařízení o ODR. 
ochrany osobních údajů stanovených jednotlivými právními řády (a směrnicí o ochraně osobních údajů). ${ }^{66}$

Přestože nařízení o ODR platformě stanovilo, že celý systém má být plně funkční k 9. lednu 2016, s odvoláním na nutné testování systému a potřebnou konzultaci se zainteresovanými subjekty, zabývajícími se řešením spotřebitelských sporů, došlo ke spuštění ODR platformy až 15. února $2016 .{ }^{67}$

\section{POSTUP PŘI ŘEŠENÍ SPOTŘEBITELSKÝCH SPORŮ $S$ VYUŽITÍM ODR PLATFORMY ${ }^{68}$}

Následující text se zaměří na postup při řešení sporů ze strany spotřebitele jako stěžovatele; je však třeba mít na paměti, že ODR platforma může za specifických podmínek sloužit také obchodníkovi, kterému umožňuje podat stížnost proti spotřebiteli. ${ }^{69}$

${ }^{66}$ Směrnice Evropského parlamentu a Rady 95/46/ES ze dne 24. ř́jna 1995 o ochraně fyzických osob v souvislosti se zpracováním osobních údajů a o volném pohybu těchto údajů. In: EUR-Lex [právní informační systém]. Úřad pro publikace Evropské unie [cit. 22. 3. 2017]. Dostupné z: http://eur-lex.europa.eu/legal-content/CS/TXT/? qid $=1463927078970 \& u r i=$ CELEX:31995L0046. K otázkám ochrany osobních údajů v rámci evropského režimu ODR více viz HÖRNLE, Julia. Encouraging Online Dispute Resolution in the EU and Beyond-Keeping Costs Low or Standards High? European Law Review, London: Sweet \& Maxwell, 2013, roč. 38, s. 187-208. ISSN 03075400. S. 204-208.

${ }^{67}$ Solving disputes online: New platform for consumers and traders [online]. European Commission - Press release [cit. 24. 3. 2017]. Dostupné z: http://europa.eu/rapid/press-release_IP16-297_en.htm

${ }^{68}$ Tato kapitola vychází částečně z: LOUTOCKÝ, Pavel. Practical Impacts of the EU Regulation on Online Dispute Resolution for Consumer Disputes. In Klára Drličková, Tereza Kyselovská. COFOLA INTERNATIONAL 2016. Brno: Masaryk University, 2016. s. 254-268, 15 s. ISBN 978-80-210-8356-1.

${ }^{69}$ Nařízení o ODR se vztahuje rovněž na mimosoudní řešení sporů, „které zahájil obchodník vůči spotřebiteli, pokud právní prèedpisy členského státu, v němž má spotréebitel obvyklé bydliště, umožňuji ř řšit takové spory prostřednictvím subjektu alternativního řešení sporù. " Článek 2 odst. 2. Nařízení o ODR. Vzhledem $\mathrm{k}$ tomu, že tato možnost řešení sporů je v současné chvíli upozaděna, nebudeme se jí v tomto článku dále zabývat. 


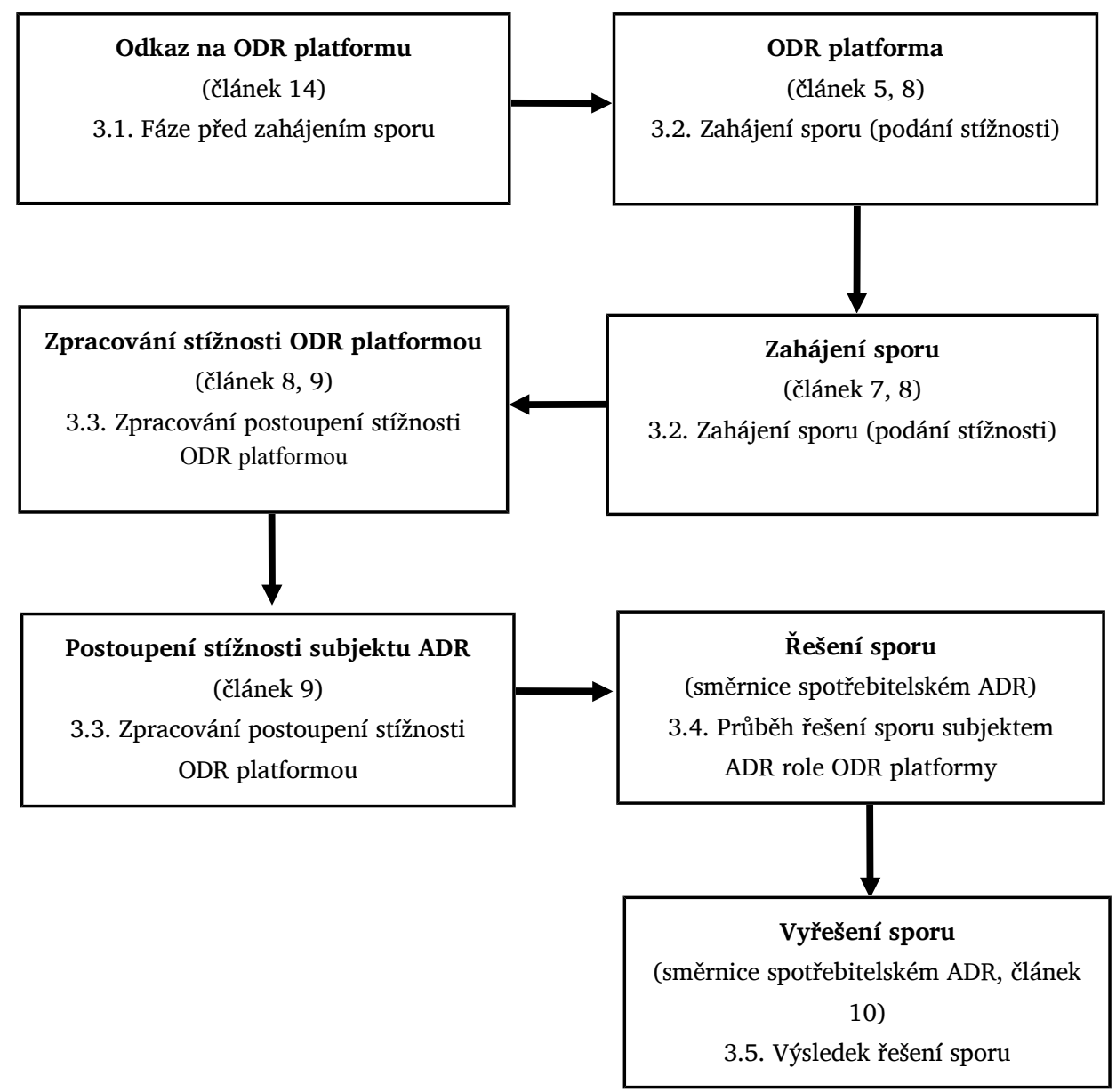

Obrázek č. 1: Schéma postupu při řešení spotřebitelských sporů online dle nařízení o ODR s využitím ODR platformy

\subsection{FÁZE PŘED ZAHÁJENÍM SPORU}

Aby se spotřebitel vůbec dozvěděl o možnosti řešit jeho spor $s$ využitím ODR platformy, nařízení o ODR klade na obchodníky požadavek, aby uvedli „na svých internetových stránkách elektronický odkaz na platformu pro řšení sporů on-line. Tento odkaz musí být pro spotřebitele snadno dostupný “" ${ }^{\prime 70}$ Úče-

70 Článek 14 odst. 1. Nařízení o ODR. 
lem je tak již před zahájením řešení sporu, respektive před vznikem sporu, spotřebitele upozornit na to, že nemusí spoléhat jen na soudní mechanismy, ale může využít specificky navrženého online nástroje.

Jestliže se obchodníci zavázali $\mathrm{k}$ tomu, že $\mathrm{k}$ řešení sporů se spotřebiteli budou využívat subjekty alternativního řešení sporů (či jsou $\mathrm{k}$ tomu povinni), ${ }^{71}$ informují rovněž o této skutečnosti spotřebitele a př́ípadně tuto skutečnost uvedou ve všeobecných obchodních podmínkách. ${ }^{72}$

\subsection{ZAHÁJENÍ SPORU (PODÁNÍ STÍŽNOSTI)}

Celý proces mimosoudního řešení sporů online je zahájen podáním stížnosti spotřebitelem. ${ }^{73}$ Za tímto účelem vyplní stěžovatel elektronický formulář pro podávání stížností na stránkách ODR platformy. Tento formulárir ${ }^{74}$ sestává z jednotlivých kroků (ty jsou vyobrazeny v Př́loze č. 1: Obrázková př́loha): (a) výběr jazyka; ${ }^{75}$ (b) podání stížnosti spotřebitelem či obchodníkem; ${ }^{76}$ (c) výběr základních informací; $;^{77}$ (d) vyplnění údajů o obchodníkovi; $^{78}$ (e) vyplnění podrobností o stížnosti; ${ }^{79}$ (f) uvedení údajů o spotřebiteli; ${ }^{80}(\mathrm{~g})$ odeslání stížnosti a potvrzení odeslání emailem. ODR platforma automaticky zkontroluje, jestli byly údaje v systému vyplněny (nekontroluje však nijak jejich správnost). S vyplňováním informací pak spotřebiteli př́ípadně asistují spotřebitelská centra v rámci sítě ECC-Net.

71 Článek 13 odst. 1 . Směrnice o spotřebitelském ADR.

${ }^{72}$ Informace o konkrétních subjektech alternativního řešení sporů, $\mathrm{k}$ jejichž využívání se obchodník zavázal, budou spotřebiteli rovněž poskytnuty při podání stížnosti. Bod 16 př́lohy $\mathrm{k}$ nařízení o ODR.

73 Článek 8. Nařízení o ODR.

74 Úvodní stránka - řě̌ení sporů online [online]. Evropská komise [cit. 15. 3. 2017]. Dostupné z: https://webgate.ec.europa.eu/odr/

${ }^{75}$ Obrázek č. 2: Výběr jazyka.

${ }^{76}$ Obrázek č. 3: Podání stížnosti.

$77 \mathrm{~V}$ tomto kroku je předmětné, zda spotřebitel žije v některém členském státě, jestli bylo zboží či služba pořízena přes internet a podává-li spotřebitel stížnost prostřednictvím někoho jiného. $\mathrm{V}$ případě, že je uvedena oblast sporů, na které se evropský právní rámec nevztahuje, ODR platforma na to upozorní a řešení sporu tak nepokračuje. Obrázek č. 4: Vyplnění základních informací.

${ }^{78}$ V tomto kroku je možno vyplnit, případně dohledat kontaktní údaje o obchodníkovi, proti kterému spotřebitel stížnost podává. Obrázek č. 5: Údaje o obchodníkovi. 


\subsection{ZPRACOVÁNÍ A POSTOUPENÍ STÍŽNOSTI ODR PLATFORMOU}

Hlavním účelem ODR platformy je zpracování údajů o stížnosti, jejich přeložení a zaslání „snadno srozumitelným způsobem a neprodleně odpưrci.“"11 Tyto informace jsou doplněny o seznam dostupných subjektů alternativního řešení sporü ${ }^{82}$ včetně upozornění, že se strany na takovém subjektu musí shodnout; rovněž je uveden údaj o př́slušném kontaktním místě v daném členském státě. Odpưrce (obchodník) má pak deset dní k tomu, aby uvedl, zda je ochoten (či povinen) ${ }^{83}$ využít $\mathrm{k}$ vyřešení konkrétního sporu se spotřebitelem subjekt alternativního řešení sporů. Je nutno zdůraznit, že účast obou stran na takovémto způsobu řešení sporů je dobrovolná, a tedy „pokud se strany sporu nedohodnou nebo př́slušný subjekt alternativního řešení sporů nebude určen, stížnost nebude dále zpracována. “84

Funkcí ODR platformy je de facto „jen“ přenos informací mezi účastníky a asistence při výběru správného subjektu ADR, který se bude zabývat sporem. Pokud strany mluví rozdílnými jazyky, ODR platforma přeloží obchodníkovi stížnost. ODR platforma tak nijak nezasahuje do samotného procesu rozhodování a funguje pouze jako zprostředkovatel informací mezi stranami. Př́padné rozhodnutí sporu je tedy ponecháno jen na subjektu al-

\footnotetext{
${ }^{79}$ V této fází spotřebitel identifikuje zboží (službu), den koupě, cenu, referenční číslo objednávky, druh stížnosti (např́íklad zda se jednalo o dodání vadného zboží, zboží neodpovídalo objednávce, zboží nebylo vůbec dodáno, zboží není možno reklamovat na základě zákonných požadavků či smluvních závazků, atp.), podrobně popíše vzniklou situaci a o co konkrétně žádá. Dále pak ke stížnosti může spotřebitel připojit související podklady. Uvádí rovněž, jestli již v minulosti kontaktoval obchodníka, jestli již v minulosti spor řešil (např́íklad již podal žalobu), či jestli obchodník požaduje věc postoupit konkrétnímu subjektu řešení sporů. Obrázek č. 6: Podrobnosti stížnosti.

${ }^{80} \mathrm{~V}$ tomto kroku spotřebitel vyplní kontaktní údaje o své osobě (jméno, bydliště, email, telefonní číslo) a př́ípadně pokud je jinou osobou zastupován, tak i její kontaktní údaje. Rovněž vybere jazyk, kterým bude s ODR platformou komunikovat. Obrázek č. 7: Osobní údaje.

81 Článek 9 odst. 3. Nařízení o ODR.

${ }^{82} \mathrm{~V}$ rámci seznamu jsou uvedeny také kontaktní informace subjektech ADR, jejich internetová adresa, poplatky za řízení, jazyk (jazyky), ve kterých subjekt operuje, průměrná délka procesu a závazný či nezávazný charakter alternativního řešení sporů. Článek 9 odst. 5. Nařízení o ODR.

${ }^{83}$ Článek 9 odst. 2 písm. a). Směrnice o spotřebitelském ADR.

84 Článek 9 odst. 3 písm. a). Nařízení o ODR.
} 
ternativního řešení sporů, pokud se na tomto režimu strany vzájemně dohodnou. ${ }^{85}$

\subsection{PRŮBĚH ŘEŠENÍ SPORU SUBJEKTEM ADR A ROLE ODR PLATFORMY}

Právě v této fázi řešení sporu je propojení nařízení o ODR a směrnice o spotřebitelském ADR nejužší. ODR platforma postoupí stížnost subjektu alternativního řešení sporů (pokud se na tom strany se subjektem dohodly) ${ }^{86}$ a další řešení je procesně podřízeno pravidlům subjektu ADR. $V$ této chvíli je role ODR platformy jako zprostředkovatele dokončena a spor je tak řešen primárně na základě pravidel subjektu ADR ( $\mathrm{a} v$ jeho gesci) a sekundárně ovlivněn požadavky směrnice $o$ spotřebitelském ADR a právním ráádem daného státu. Po obdržení stížnosti je pak subjekt ADR povinen informovat ODR platformu o tom, že informace o sporu obdržel a potvrdit, že se jím bude opravdu zabývat. ${ }^{87}$ Subjekt alternativního řešení sporů musí na základě svých pravidel ve lhůtě 90 kalendárních dnů dát $\mathrm{k}$ dispozici výsledek sporu. „U velmi složitých sporů může př́slušný subjekt alternativního řešení sporů tuto lhůtu 90 kalendářních dnů na základě vlastního uvážení prodloužit. “88 Je rovněž uvedeno, že jedním ze základních principů ODR režimu je nenutit nijak strany $\mathrm{k}$ fyzické př́itomnosti při řešení sporu, pokud se nedomluví jinak. ${ }^{89}$

\footnotetext{
85 Rovněž samotný subjekt ADR může odmítnout řešení sporu v případě, že se spotřebitel nepokusil kontaktovat dotčeného obchodníka, aby ním svoji stížnost projednal a pokusil se tak nejprve danou věc řešit přímo s ním. Článek 5 odst. 4 písm. a). Směrnice o spotřebitelském ADR.

${ }^{86}$ „Pokud se strany sporu do 30 kalendářních dnů od předložení formuláře pro podávání stížnosti nedohodnou na jednom subjektu alternativního řešení sporů nebo pokud se subjekt alternativního řě̌ení sporů odmítne sporem zabývat, stížnost nebude dále zpracovávána. “ Článek 9 odst. 8. Nař́zení o ODR.

87 Článek 9 odst. 7. Nařízení o ODR.

88 „Strany musí být informovány o prodloužení této lhůty a o celkové době, do kdy lze očekávat, že bude spor ukončen. “ Článek 8 písm. e). Směrnice o spotřebitelském ADR.

89 Recitál 42. Směrnice o spotřebitelském ADR.
} 
Je ovšem zdůrazněno, že subjekt alternativního řešení sporu není povinen ODR platformu k řešení sporu využít, ${ }^{90}$ i když je to doporučeno. ${ }^{91}$ Ve fázi řešení sporu tedy ODR platforma stále působí jen jako zprostředkovatel informací ( $v$ této fázi sbírá informace o vyřešených případech a zveřejňuje statistiky o využívání daného řešení) a nijak se nepodílí na samotném urovnání sporu.

\subsection{VÝSLEDEK ŘEŠENÍ SPORU}

Je stanoveno, že v případě spotřebitele vždy a v případě obchodníka tehdy, pokud není určeno jinak, ${ }^{92}$ má být zajištěna možnost, aby strany ukončily „svoji účast $v$ postupu $v$ kterékoli jeho fázi, pokud jsou nespokojeny s jeho prováděním nebo průběhem. “93 Pokud by tomu bylo jinak, Hodges, Benöhr a Creutzfeldt-Banda zdo̊razňují, že by se jednalo o nepřiměřené smluvní podmínky, ${ }^{94}$ což by bylo v rozporu s právními principy EU. ${ }^{95}$ Zejména spotřebitel může kdykoli svůj souhlas odvolat. Před tím, než strany svůj sou-

90 Článek 10 písm. d). Nařízení o ODR.

${ }^{91}$ Nařízení o ODR v této souvislosti zdůrazňuje možnost využít elektronické komunikace a rovněž nástroje pro elektronickou správu případů. Recitál 18 a článek 5 odst. 4. písm. d). Nařízení o ODR.

92 „Členské státy zajistí, aby př̀ postupech alternativního řešení sporů, které se zaměrují na řešení sporu nařízením řešení, bylo nařizené řešení pro strany závazné, pouze pokud byly informovány o jeho závaznosti předem a výslovně s ní souhlasily. Od obchodníků není požadován zvláštní souhlas, pokud vnitrostátní právní předpisy stanoví, že řešení jsou pro obchodníky závazná. “ Článek 10 odst. 2. Směrnice o spotřebitelském ADR.

${ }_{93}$ „O tomto právu musí být informovány před začátkem postupu. “ Článek 9 odst. 2 písm. a). Směrnice o spotřebitelském ADR.

94 Za nepřiměřené smluvní podmínky jsou považovány takové podmínky, které spotřebitele nutí $\mathrm{k}$ tomu, aby se účastnil rozhodčího řízení a nebyl mu tak umožněn přístup $\mathrm{k}$ soudu. Článek 6 a článek 1 odst. q) př́lohy. Směrnice Rady 93/13/EHS ze dne 5. dubna 1993 o nepřiměřených podmínkách ve spotřebitelských smlouvách. In: EUR-Lex [právní informační systém]. Úřad pro publikace Evropské unie [cit. 22. 3. 2017]. Dostupné z: http://eur-lex.europa.eu/legal-content/CS/TXT/qid = 1464014662319\&uri = CELEX: 31993L0013

Celá dobrovolnost procesu zejména $\mathrm{v}$ závazné fázi byla potvrzena v rozsudku Soudního dvora ve věci C-168/05, kde bylo zdůrazněno, že i v případě, že byla sjednána rozhodčí doložka se zneužívajícím charakterem a spotřebitel po zahájení rozhodčího řízení svou účast ve lhůtě neodmítl, neznamená to, že by byl nález vykonatelný, pokud se spotřebitel obrátil př́ímo na soud. Rozsudek Soudního dvora (prvního senátu) ze dne 26. října 2006. Elisa María Mostaza Claro proti Centro Móvil Milenium SL. Věc C-168/05. In: Sbírka rozhodnutí. 2006, s. I-10421. 
hlas s navrhovaným řešením sporů vyjádří, musí být rovněž informovány právních důsledcích takového souhlasu. ${ }^{96}$ A priori je ale vyloučeno, aby dohoda mezi spotřebitelem a obchodníkem o využití alternativního řešení sporů (bez rozdílu, jestli se jedná o nezávazné či závazné řízení vedené online či offline) byla zavazující, pokud byla uzavřena před vznikem sporu ${ }^{97}$ a pokud zbavuje spotřebitele možnosti kdykoli podat návrh na zahájení řízení u soudu. ${ }^{98}$ Cortés ${ }^{99}$ proto zdůrazñuje, že na základě směrnice o ADR je tedy znemožněno sjednat zejména rozhodčí doložku, která je součástí smlouvy hlavní, před vznikem sporu. ${ }^{100}$ Při ukončení rozhodování je pak subjekt ADR povinen informovat ODR platformu o výsledku sporu. ${ }^{101}$

95 HODGES, Christopher J., Iris BENÖHR a Naomi CREUTZFELDT-BANDA. Consumer ADR in Europe: Civil Justice Systems. Oxford: Hart publishing, 2012, 503 s. ISBN 9781849463485. S. 416.

96 Před vyjádřením souhlasu musí být strany konkrétně upozorněny na to, že „i) mají možnost se rozhodnout, zda budou či nebudou s navrhovaným řešením souhlasit, nebo zda se jím budou ř́dit, ii) účast na postupu nevylučuje možnost domáhat se zjednání nápravy prostrednictvím soudních ř́zení, iii) navrhované řešení se může lišit od výsledku, ke kterému by dospěl soud na základě právních pravidel.“ Článek 9 odst. 2 písm. b). Směrnice o spotřebitelském ADR.

97 Ve Spojených státech amerických je ale situace opačná a spotřebitelské rozhodčí řízení zde má poměrně velkou tradici. Uzavření rozhodčí doložky spotřebitelem ještě před vznikem sporu je prozatím v zásadě povoleno. V současné chvíli byla ale představena novela $A r-$ bitration Fairness Act of 2015, která by danou možnost měla znemožnit. Arbitration Fairness Act of 2015. S.1133 - 114th Congress [online]. The United States Congress [cit. 23. 3. 2017]. Dostupné z: https://www.congress.gov/bill/114th-congress/senate-bill/1133

Novela byla představena ale také díky sílící kritice v souvislosti se skupinovými žalobami (anglicky class aciton), zejména co se týče vysokého profitu právních zástupců možné šikany spotřebitelů. tom více CORTÉS, Pablo. Enforcing EU Consumer Policy through Different Layers: Combining the Judicial and the Out-of-Court Mechanisms [online]. University of Leicester School of Law Research Paper No. 14-27, 2014 [cit. 22. 3. 2017]. Dostupné z: http://papers.ssrn.com/sol3/papers.cfm?abstract_id=2520487. S 4, 8-9.

98 Článek 10 odst. 1 . Směrnice o spotřebitelském ADR.

99 CORTÉS, Pablo. New Regulatory Framework for Extra-judicial Consumer Redress: Where We Are and How to Move Forward. Legal Studies, 2015, roč. 35, č. 1, s. 114-141. ISSN 1748-121X. S. 125.

100 To naznačoval rovněž již v minulosti rozsudek Soudního dvora ve věci C-40/08, který uzavření rozhodčí doložky spotřebitelem před vznikem sporu po nenaplnění striktního kritéria informovat spotřebitele o důsledcích rozhodčího řízení staví na roveň rozporu s veřejným pořádkem. Rozsudek Soudního dvora (prvního senátu) ze dne 6. října 2009. Asturcom Telecomunicaciones SL proti Cristina Rodríguez Nogueira. Věc C-40/08. In: Sbírka rozhodnutí. 2009, s. I-09579. 
Evropský právní rámec samotný nevylučuje, aby byl konečný výsledek sporu nejen nezávazný (negociace, mediace), ale závazný (rozhodčí ř́zení). ${ }^{102}$ Zejména $\mathrm{v}$ případě závazného rozhodnutí je ale třeba mít na paměti zvýšenou ochranu spotřebitele (která je odlišná v různých členských státech) ve všech fázích rozhodovacího procesu od uzavření rozhodčí doložky až po finální rozhodnutí a jeho vykonatelnost. V této souvislosti uvádíme, že v České republice již není možno ve spotřebitelských sporech platně sjednat rozhodčí doložku, a to na základě zákona č. 258/2016 Sb., kterým se mění některé zákony v souvislosti s přijetím zákona o spotřebitelském úvěru. ${ }^{103} \mathrm{~V}$ případě nezávazných způsobů řešení sporů (negociace, mediace) je pak klíčová motivace stran k urovnání sporu a k uzavření vzájemné dohody. Strany ale vždy musí dodržovat jejich smluvní závazek, pokud došlo k uzavření finální dohody a strany tak potvrdili vzájemný smír či doporučení třetí strany.

\section{DOPADY EVROPSKÉ PRÁVNÍ ÚPRAVY SPOTŘEBITELSKÉHO (ONLINE) MIMOSOUDNÍHO ŘEŠENÍ SPORŮ NA ČESKÝ PRÁVNÍ ŘÁD}

Tato kapitola vymezí dopady představené evropské právní úpravy mimosoudního řešení sporů na český právní řád. Novela ZOS implementací směrnice o spotřebitelském ADR nově zavedla specifický režim pro řešení sporů mimosoudně, kdy jednou ze zúčastněných stran je spotřebitel. ${ }^{104} \mathrm{Ne}-$ znamená to však, že by spotřebiteli nebylo umožněno využít jiných mechanismů mimosoudního řešení sporů. Pokud se rozhodne nepodstoupit mi-

${ }^{101}$ Subjekt alternativního řešení sporů je povinen postoupit ODR platformě informace o datu, kdy mu byla doručena stížnost, předmětu sporu, datum, kdy bylo ukončeno mimosoudní řešení sporu a výsledek samotného postupu alternativního řešení sporu. Tyto informace sloužící k evidenci úspěšnosti mimosoudního řešení sporů subjekt ADR postoupí ODR platformě vždy bez prodlení. Článek 9 odst. 5, 6. Nařízení o ODR.

${ }^{102}$ Pokud se členské státy rozhodnou, může se směrnice o spotřebitelském ADR „vztahovat rovněž na subjekty alternativního řešení sporů, kterým členské státy povolily nařizovat stranám sporu závazná řešení. Mimosoudní postup vytvořený ad hoc pro konkrétní spor mezi spotřebitelem a obchodníkem by však neměl být považován za postup alternativního řešení sporů, “ a směrnice by na něj tak neměla jakkoli dopadat. Recitál 20. Směrnice o spotřebitelském ADR.

${ }^{103}$ Tento zákon nabyl účinnosti dne 1. 12. 2016. 
mosoudní řešení sporů upravené v § 20d a násl. ZOS $^{105}$ (implementované na základě směrnice o spotřebitelském ADR), může využít negociace, neformální mediace či mediace upravené na základě zákona o mediaci. ${ }^{106}$

Tyto zákonem upravené způsoby řešení sporů však nejsou primárně orientovány na řešení spotřebitelských sporů. Cílem této kapitoly je detailnější analýza dopadu směrnice o spotřebitelském ADR na český právní řád, možnost využití online řešení sporu a aplikační problémy s tím spojené. Součástí kapitoly budou rovněž návrhy na úpravu de lege ferenda.

\subsection{IMPLEMENTACE SMĚRNICE O SPOTŘEBITELSKÉM ADR DO ZOS}

Právní úprava reagující na evropský režim mimosoudního řešení spotřebitelských sporů se promítla zejména do ZOS, kterým byl zaveden specifický postup pro mimosoudní řešení spotřebitelských sporů. Důvodová zpráva ${ }^{107}$ uvádí, že jejím účelem bylo vytvoření jednotného a transparentního systé$\mathrm{mu}$, který by měl spotřebitelům umožnit orientaci $\mathrm{v}$ jejich právech a napomoci k jejich vymáhání. „Navrhovaná právní úprava dále umožní spotřebitelům řešit své přeshraniční spotřebitelské spory on-line, což se zejména uplatní $v$ př́padě sporů z internetového obchodu. “108 Snahou novely $\operatorname{ZOS}^{109}$ bylo mj. sjednotit systém mimosoudního řešení sporů, který by zahrnoval všechny

${ }^{104}$ Definice spotřebitele je zahrnuta v českém právním řádu zejména $\mathrm{v} \S 419$ zákona č. 89/2012 Sb., občanský zákoník, ve znění pozdějších předpisů a $\S 2$ odst. 1 písm. a) ZOS. Více k pojmu „spotřebitel“ v českém právním řádu viz Analýza úpravy alternativních řešení sporů v jiných státech Evropské unie a judikatura soudů České republiky [online]. „Alternative Dispute Resolution“ (ADR) v Evropské unii a v České republice. Nejvyšší soud, úsek místopředsedy NS, oddělení evidence judikatury, 19. května 2014 [cit. 25. 3. 2017]. Dostupné z: http://www.nsoud.cz/JudikaturaNS_new/ns_web.nsf/0/86b6869e71f6e147 c1257f6c00530d32/\$FILE/Alternative\%20Dispute\%20Resolution_ADR.pdf. S. 56-57.

${ }^{105}$ Zákon č. 634/1992 Sb., zákon o ochraně spotřebitele, ve znění pozdějších předpisů (dále jen „ZOS“).

${ }^{106}$ Zákon č. 202/2012 Sb., o mediaci a změně některých zákonů (zákon o mediaci), ve znění pozdějších předpisů (dále jen „ZM“).

${ }^{107}$ Důvodová zpráva k zákonu č. 378/2015 Sb., kterým se mění zákon č. 634/1992 Sb., o ochraně spotř̌ebitele, ve znění pozdějších předpisů, a některé další zákony. Sněmovní tisk 445/0, část č. 1/16 [online]. Poslanecká sněmovna Parlamentu České republiky [cit. 29. 3. 2017). Dostupné z: https://www.psp.cz/sqw/text/tiskt.sqw?O $=7 \& \mathrm{CT}=445 \& \mathrm{CT} 1=0$ (dále jen „důvodová zpráva“).

${ }^{108}$ Ibidem. S. 34. 
oblasti sporů, protože dostupnost mechanismů byla do doby novely ZOS fragmentovaná.

V rámci mimosoudních mechanismů pro řešení spotřebitelských sporů $\S 20$ e ZOS zmiňuje, že $\mathrm{k}$ řešení specifických sporů v oblasti finančních služeb je možno využít specializovaných subjektı̊ - v oblasti finančních služeb finančního arbitra, ${ }^{110} \mathrm{v}$ oblasti elektronických komunikací a poštovních služeb Český telekomunikační úřad ${ }^{111}$ a v oblasti elektroenergetiky, plynárenství a teplárenství Energetický regulační úřad. ${ }^{112}$ Tyto mechanismy byly spotřebiteli dostupné již v minulosti a na základě novely ZOS „jen“ přibyl jejich taxativní výčet za účelem vhodnějšího upozornění spotřebitele na možnost využití řešení sporů v dané oblasti. ${ }^{113}$ Tyto stávající (více formalizované) možnosti řešení spotřebitelských sporů byly novelou ZOS nedotčeny (až na formální úpravy) díky jejich již prokázané efektivitě. ${ }^{114}$

\footnotetext{
${ }^{109}$ Novela ZOS nezahrnuje jen implementaci mimosoudního řešení spotřebitelských sporů; v souladu s tématem tohoto článku bude však další část textu zaměřena jen na otázky související s implementací směrnice o spotřebitelském ADR do českého právního řádu zakotvené v § 20d - 20y ZOS.

${ }^{110} \mathrm{~V}$ případě specifického spotřebitelského řízení u finančního arbitra (které ale není rozhodčím řízením na základě zákona o rozhodčím řízení) je nález jím vydaný nutno považovat za soudně vykonatelný, jakmile uběhne lhůta k plnění (s odkazem na zákon č. 99/1963 Sb., občanský soudní řád, ve znění pozdějších předpisů). Při řešení sporů není poskytnuta možnost řešit spor online, i když je umožněno spor online zahájit a využít datových schránek a př́padně zaručeného elektronického podpisu. § 17 a § 24 zákona č. 229/2002 Sb., finančním arbitrovi, ve znění pozdějších předpisů.

${ }^{111}$ Řízení vedené Českým telekomunikačním úřadem ve stanovených spotřebitelských sporech (ř́zení o námitkách proti vyřízení reklamace) neposkytuje možnost online řešení sporů; umožňuje ale využít ke komunikaci datové schránky nebo uznávaného elektronického podpisu; vydává rozhodnutí v rámci zákona č. 500/2004 Sb., správní řád, ve znění pozdějších předpisů. Řízení samotné je pak upraveno zákonem č. 127/2005 Sb., o elektronických komunikacích a o změně některých souvisejících zákonů (zákon o elektronických komunikacích), ve znění pozdějších předpisů.

112 Řízení spotřebitelských sporů vedené Energetickým regulačním úřadem je podobné jako řízení vedené u Českého telekomunikačního úřadu i co se týče využití nástrojů elektronické komunikace, nicméně na rozdíl od řízení u Českého telekomunikačního úřadu není v konkrétních sporech pravomoc Energetického regulačního úřadu výlučná. Lze rovněž využít služeb ombudsmana či oddělení ochrany spotřebitele, kteří vydávají nezávazná doporučující stanoviska. Zákon č. 458/2000 Sb., o podmínkách podnikání a o výkonu státní správy v energetických odvětvích a o změně některých zákonů (energetický zákon), ve znění pozdějších předpisů.

${ }^{113} \S 20 \mathrm{e}$. ZOS.
} 
Vedle těchto existujících mechanismů ve specifických oblastech byla nově zavedena možnost mimosoudně řešit spotřebitelské spory ${ }^{115} \mathrm{u}$ České obchodní inspekce (dále jen „ČOI“) a dalších subjektů pověřených Ministerstvem průmyslu a obchodu ${ }^{116}$ tak, aby bylo umožněno řešit spory „prakticky ve všech odvětvích [...], a to rovněž prostřednictvím on-line prostředků. “117 Pověřeným subjektem pro řešení spotřebitelských sporů je rovněž Sdružení českých spotřebitelů, z.ú. (dále jen „SČS“). Dalším pověřeným subjektem v oblasti sporů mezi advokátem a klientem spotřebitelem je v České republice Česká advokátní komora (dále jen „ČAK“). ${ }^{118}$

Na základě právní úpravy zakotvené v § 20n a násl. ZOS je poskytované řešení vymezeno jako konciliační. Tím, že směrnice o spotřebitelském ADR nestanovuje konkrétní požadavky na metodu řízení (díky rozdílné tradici v různých členských státech), není však konciliace jedinou využívanou metodou. Pro srovnání uvádíme Španělsko, kde je ve vysoké míře využíváno arbitráže, v Itálii je to mediace a ve Spojeném království pak konciliace (resp. med-arb). ${ }^{119}$ ČOI a ČAK pak na základě § 20x ZOS stanovily vlastní pravidla, kterými upravily podrobněji postup při mimosoudním řešení spo-

${ }^{114}$ Důvodová zpráva $\mathrm{k}$ tomu uvádí, že není „žádoucí (ani účelné) do těchto fungujicích systémů zasahovat (s výjimkou jejich uvedení do souladu s evropskou legislativou)" a dále poskytuje přehled o počtu vyřešených sporů s využitím daných specifických možností pro řešení sporu. Důvodová zpráva. S. 43, 52-55.

${ }^{115}$ Právě na tento způsob mimosoudního řešení sporů se další část textu zaměří.

${ }^{116} \S 20$ e písm. d). ZOS.

${ }^{117}$ Důvodová zpráva. S. 37.

${ }^{118}$ Seznam všech subjektů mimosoudního řešení sporů je uveden na stránkách Ministerstva průmyslu a obchodu včetně základních informací o jednotlivých subjektech (kontaktní údaje, poplatky, jazyky, atd.). Seznam subjektů mimosoudního řešení spotřebitelských sporů [online]. Ministerstvo průmyslu a obchodu [cit. 29. 3. 2017]. Dostupné z: http://www.mpo.cz/dokument171389.html

${ }^{119} \mathrm{~K}$ tomu více CORTÉS, Pablo. The impact of EU law in the ADR landscape in Italy, Spain and the UK: time for change or missed opportunity? ERA Forum, Berlin, Heidelberg: Springer Berlin Heidelberg, 2015, roč. 16, č. 2, s. 125-147. ISSN 18639038. S. 131-141. K situaci v ostatních členských státech viz Analýza úpravy alternativních řešení sporů v jiných státech Evropské unie a judikatura soudu České republiky [online]. „Alternative Dispute Resolution“ (ADR) v Evropské unii a v České republice. Nejvyšší soud, úsek místopředsedy NS, oddělení evidence judikatury, 19. května 2014 [cit. 29. 3. 2017]. Dostupné z: http://www.nsoud.cz/JudikaturaNS_new/ns_web.nsf/0/86b6869e71f6e147c1257f6c00530 d32/\$FILE/Alternative\%20Dispute\%20Resolution_ADR.pdf. S. 33-45. 
rů s účinností od 1. února $2016 .{ }^{120}$ SČS pak vydalo taková pravidla v srpnu $2016 .^{121}$

Cílem novely ZOS v oblasti mimosoudního řešení sporů bylo právě pro tyto subjekty mimosoudního řešení sporù ${ }^{122}$ stanovit pravidla spotřebitelského ADR na základě požadavků směrnice o spotřebitelském ADR a zlepšit možnost řešit spory online $a$ přeshraničně. ${ }^{123}$ Tyto mechanismy dle $\S 20 \mathrm{~d}$ ZOS však nedopadají shodně se směrnicí o spotřebitelském ADR na spory týkající se poskytování zdravotních služeb, vyššího vzdělání navíc na služby obecného zájmu nehospodářské povahy. ${ }^{124}$

Ministerstvo průmyslu a obchodu jako pověřený orgán na základě směrnice o spotřebitelském ADR (a ZOS) posuzuje na základě požadavků stanovených $\mathrm{v} \S 20 \mathrm{f}$ ZOS žádosti subjektů a $\mathrm{v}$ př́padě pozitivního roz-

${ }^{120}$ Pravidla ČOI jsou dostupná zde: Pravidla pro postup při Mimosoudním řešení spotřebitelských sporů (ADR) [online]. Česká obchodní inspekce [cit. 29. 3. 2017]. Dostupné z: http://www.coi.cz/userdata/files/dokumenty-ke-stazeni/pravidla-pro-postup-adr.pdf (dále jen „pravidla ČOI“).

Pravidla ČAK jsou dostupná zde: Pravidla pro postup pověreného subjektu (České advokátní komory) při mimosoudním řešení spotřebitelských sporů [online]. Česká advokátní komora [cit. 28. 3. 2017]. Dostupné z: http://www.cak.cz/assets/pravidla-pro-postup-pri-msrss.pdf (dále jen „pravidla ČAK“).

${ }^{121}$ Pravidla SČS jsou dostupná zde: Pravidla pro postup pověřeného subjektu Sdružení českých spotřebitelů při mimosoudním řešení spotřebitelských sporů [online]. Sdružení českých spotřebitelů [cit. 28. 3. 2017]. Dostupné z: http://www.konzument.cz/users/files/resenisporu/SCS-proces-pravidla-MUS-2.pdf (dále jen „pravidla SČS“).

${ }^{122}$ Je však nutno upozornit na pojmovou nesourodost, kdy ZOS nazývá dané subjekty jako „subjekty mimosoudního řešení sporü“, nicméně český překlad směrnice o spotřebitelském ADR hovoří vždy jen o „subjektech alternativního řešení sporů.“ Přestože se může zdát, že záměna není zásadní, není úplně jednoduché na základě složitosti právních úprav na první pohled tento fakt odhalit. $\mathrm{V}$ rámci srozumitelnosti textu $\mathrm{v}$ souvislosti $\mathrm{s}$ aktuální právní úpravou budeme nicméně $\mathrm{v}$ otázkách týkajících se českého právního prostředí dále používat „subjekt mimosoudního řešení sporü“ dle terminologie ZOS.

${ }^{123} \mathrm{~V}$ České republice pak při řešení přeshraničního sporu a případně při online výměně informací asistuje Evropské spotřebitelské centrum ČR v rámci sítě ECC-Net. Mimosoudní řešení sporů (ADR) [online]. Evropské spotřebitelské centrum Česká republika [cit. 28. 3. 2017]. Dostupné z: http://www.evropskyspotrebitel.cz/mimosoudni-reseni-sporu-adr/mimosoudni-reseni-sporu-adr-63164

${ }^{124}$ K vymezení služeb obecného zájmu nehospodářské povahy více viz Rozsudek Soudního dvora (čtvrtého senátu) ze dne 12. února 2009. Vereniging Noordelijke Land-en Tuinbouw Organisatie proti Staatssecretaris van Financiën, Věc C-515/07. In: Sbírka rozhodnutí. 2009, s. I-00839. 
hodnutí je pověřuje ${ }^{125}$ výkonem ADR v dané oblasti. Pro všechny subjekty mimosoudního řešení sporů jsou shodně stanoveny povinnosti vycházející ze směrnice o spotřebitelském ADR, tedy zejména požadavky na odbornost osoby podílející se na rozhodování sporu, její nestrannost a nezávislost a obecná informační povinnost vůči spotřebiteli včetně nutnosti požadované informace publikovat na svých internetových stránkách. ${ }^{126}$

Metody nově zavedeného mimosoudního řešení spotřebitelských sporů nebyly směrnicí o spotřebitelském ADR nijak vymezeny a byly ponechány díky národním specifikům na uvážení členských států. Důvodová zpráva však zdůraznila, že přestože lze $\mathrm{k}$ řešení sporů využít mediace na základě $\mathrm{ZM}^{127}$ nebo rozhodčího řízení ${ }^{128}$ (které je však již od 1. 12. 2016 ve spotřebitelských sporech vyloučeno), ${ }^{129}$ zejména u spotřebitelského řešení sporů se tyto instituty neosvědčily; nebyly tedy pro účely transpozice optimální, a to i vzhledem $k$ efektivnějšímu využití online komunikace a ODR platformy. Možnost poskytnutí př́ímé negociace ${ }^{130}$ pak byla $\mathrm{v}$ rámci řešení sporů prostřednictvím ČOI (nebo jiného subjektu) mezi podnikatelem ${ }^{131}$ a spotřebitelem nepřímo vyloučena zákonnou úpravou. ${ }^{132}$

${ }^{125}$ Dle $\S 20 f$ ZOS ministerstvo rozhoduje o tom, kdo bude pověřeným subjektem.

${ }^{126} \S 20 \mathrm{~g}$ až $\S 20 \mathrm{k}$. ZOS. Informační povinnost $\mathrm{v}$ daném rozsahu nicméně nedopadá na finančního arbitra. § $20 \mathrm{~m}$. ZOS.

${ }^{127}$ K možnostem využití online zákonem upravené mediace více GERTNER, Lucie. Mediace online v kontextu zákona o mediaci. Bulletin advokacie, Praha: Česká advokátní komora, 2013, roč. 6/2004, s. 41. ISSN 12106348. S. 41.

${ }^{128}$ Na základě zákona č. 216/1994 Sb., o rozhodčím řízení a o výkonu rozhodčích nálezů, ve znění pozdějších předpisů.

${ }^{129}$ Viz kapitola 3.5. Výsledek řešení sporu.

${ }^{130}$ Online negociaci v rámci svých služeb poskytuje český obchodní portál Aukro. K tomu více Jak zahájit spor? - Úvod [online]. Aukro [cit. 28. 3. 2017]. Dostupné z: http://aukro.cz/country_pages/56/0/education/guide_debate/index.php

${ }^{131}$ Upozorňujeme ale, že český překlad směrnice o spotřebitelském ADR využívá pro označení druhé strany výhradně termínu „obchodník“. Důvodová zpráva na základě terminologie shodné se ZOS označuje druhou stranu jako prodávajícího, případně podnikatele. $\mathrm{V}$ rámci srozumitelnosti textu v části týkající se české právní úpravy budeme dále používat pojem „podnikatel“ dle terminologie ZOS.

${ }^{132} \mathrm{~V}$ př́́padě iniciace sporu přikládá spotřebitel mj. „doklad o skutečnosti, že se navrhovateli nepodařilo spor vyřešit $s$ druhou stranou prímo." $\S 20$ odst. 3. ZOS. 


\subsection{MIMOSOUDNÍ ŘEŠENÍ SPOTŘEBITELSKÝCH SPORŮ ONLINE NA} ZÁKLADĚ ZOS

Spor je zahájen ${ }^{133}$ návrhem ${ }^{134}$ podaným spotřebitelem subjektu mimosoudního řešení sporů obsahující základní identifikační údaje, vylíčení relevantních okolností a požadavky, kterých se spotřebitel domáhá. Spotřebitel rovněž doloží doklad o tom, že se pokoušel (neúspěšně) spor s podnikatelem řešit. ${ }^{135}$ Po doručení návrhu se $\mathrm{k}$ němu podnikatel musí do 15 pracovních dní vyjádřit. ${ }^{136}$ Celé konciliační řízení za asistence subjektu mimosoudního řešení sporů pak trvá 90 dnů v souladu se směrnicí o spotřebitelském $\mathrm{ADR}^{137}$ a je v ideálním př́padě ukončeno dohodou stran. ${ }^{138}$

ČOI poskytuje možnost kromě písemného podání zahájit spor rovněž prostřednictvím online formuláře ADR, ${ }^{139} \mathrm{k}$ čemuž ZOK uvádí následující:

„Návrh lze podat [...] elektronicky prostrednictvím on-line formuláře uvedeného na internetových stránkách České obchodní inspekce, podepsaný uznávaným elektronickým podpisem nebo zaslaný prostřednictvím datové schránky osoby, jež návrh podává. Za podmínky, že je návrh do 10 dnů potvrzen, popř́padě doplněn jedním ze zpưsobů uvedených ve větě první, je možno

${ }^{133}$ K odmítnutí návrhu dojde zejména $v$ př́ípadě, pokud je zjevně neopodstatněný, byl podán více než jeden rok poté, co spotřebitel poprvé uplatnil své právo u podnikatele, spor nenáleží do věcné působnosti subjektu nebo o něm bylo již pravomocně rozhodnuto. $\S 20 \mathrm{p}$ a § 20q. ZOS. Podáním návrhu pak s odkazem na $\S 647$ OZ, dochází k pozastavení promlčecích lhůt. § 20o. ZOS.

${ }^{134}$ Zde opět upozorňujeme na pojmovou nesourodost ZOS a směrnice o spotřebitelském ADR. Zatímco ZOS uvádí, že řešení sporu je zahájeno podáním „návrhu na zahájení mimosoudního řešení spotřebitelského sporu“, na základě směrnice o spotřebitelském ADR je řešení sporu zahájeno podáním „stížnosti.“ V rámci srozumitelnosti textu v části týkající se české právní úpravy budeme dále používat pojmu „návrh“ dle terminologie ZOS.

${ }^{135}$ Přestože není stanoveno, co je považováno za takový doklad, měl by ke splnění této podmínky spotřebiteli v př́padě online komunikace postačovat např́ílad email zaslaný podnikateli.

${ }^{136}$ Účast na řešení sporů není však ani pro podnikatele povinná.

${ }^{137}$ Ve složitých případech lze řízení prodloužit maximálně o dalších 90 dní. § 20t. ZOS.

${ }^{138} \mathrm{~V}$ případě, že se strany nedohodnou, řízení končí uplynutím stanovené lhůty, či prohlášením spotřebitele o ukončení celého řízení. § 20u. ZOS.

${ }^{139}$ Obrázek č. 8: Online formulář ADR - Česká obchodní inspekce. Uvedeno v Př́iloze č. 1: Obrázková př́loha. 
jej podat pomocí jiných technických prostředků, zejména prostřednictvím telefaxu nebo veřejné datové sítě bez použití uznávaného elektronického podpisu. “140

K této zákonné úpravě pak pravidla ČOI doplňují, že při podání návrhu prostřednictvím online formuláře ADR postačí, když bude kromě výše zmíněných způsobů návrh spotřebitelem potvrzen „krátkým písemným prohlášením vygenerovaným $v$ online formulárí, které podepsané zašle oddělení ADR. “141

V otázkách doručování a následné komunikace je pak ZOS stanoveno, že: „Povinnost České obchodní inspekce nebo pověreného subjektu doručit stranám sporu písemnost podle této části zákona je splněna, pokud je doručena prostřednictvím veřejné datové sítě do datové schránky adresáta, na adresu uvedenou $v$ návrhu na zahájení mimosoudního řšení spotřebitelského sporu nebo na adresu, a to i elektronickou, kterou za účelem doručování sdělí strany sporu České obchodní inspekci nebo pověřnému subjektu. Písemnost se považuje za doručenou $i v$ př́padě, že se adresát o doručení z důvodů okolností na jeho straně nedozvěděl. “"142

Předpokladem při mimosoudním řešení spotřebitelských sporů v rámci mechanismu poskytnutého ČOI bylo, že počet podání bude dosahovat 6.000 př́ípadů ročně. ${ }^{143} \mathrm{~V}$ minulém roce bylo dle informací poskytnutých ČOI $\mathrm{v}$ rámci $\mathrm{ADR}$ mechanismu celkově evidováno přibližně 300 sporů měsíčně. 80 \% návrhů bylo podáno prostřednictvím online formuláře ADR dostupného na stránkách ČOI. ${ }^{144}$ Tento fakt naznačuje, že by využití online způsobu řešení sporů mohlo být mezi spotřebiteli obecně populární i díky tomu, že formulář na stránkách je jednoduše dostupný a poměrně přehledný. $90 \%$ návrhů podaných prostřednictvím online formuláře ADR však spotřebitelé potvrzují písemným prohlášením zaslaným ČOI poštou, ${ }^{145}$ tedy jen $10 \%$ spotřebitelů využívá $\mathrm{k}$ podání uznávaného elektronického podpisu nebo vy-

\footnotetext{
${ }^{140} \S 20$ odst. 4. ZOS.

${ }^{141}$ Článek 6 odst. 5). Pravidla ČOI.

${ }^{142} \S 20 \mathrm{v}$. ZOS.

${ }^{143}$ Důvodová zpráva. S. 52.

${ }^{144}$ Formulář návrhu na zahájení ř́zení o mimosoudním řešení spotrebitelského sporu (ADR) [online]. Česká obchodní inspekce [cit. 28. 3. 2017]. Dostupné z: https://adr.coi.cz/cs/form

${ }^{145}$ Dle způsobu uvedeného v článku 6 odst. 5). Pravidla ČOI.
} 
generovaný návrh zasílají datovou schránkou. ${ }^{146}$ ČOI pak eviduje úspěšné dohody mezi spotřebitelem a podnikatelem a udává, že bylo vyřešeno smírně přibližně 80 sporů měsíčně. ${ }^{147}$

$\mathrm{Z}$ výše uvedeného je patrné, že mimosoudní řešení sporů poskytované ČOI je v minimu případů vedeno výhradně s využitím online prostředí. Důvod shledáváme zejména $\mathrm{v}$ tom, že na podání návrhu na zahájení mimosoudního řešení spotřebitelského sporu jsou kladeny příliš formální nároky (přestože cílem bylo zavést co nejméně formální řízení), ${ }^{148}$ tedy že pro iniciování celého sporu online je třeba využít uznávaného elektronického podpisu nebo datové schránky fyzické osoby (spotřebitele). Datové schránky jsou však v České republice využívány minimem fyzických osob, u kterých je ale největší pravděpodobnost, že budou vystupovat právě v pozici spotřebitele. ${ }^{149}$ Rovněž uplatnění uznávaného elektronického podpisu není více rozšǐřené. ${ }^{150}$ Přestože lze předpokládat vzrůstající využití těchto instrumentů, ${ }^{151}$ není vhodné po spotřebitelích požadovat, aby těchto nástrojů využívali v souvislosti s daným, méně formalizovaným mimosoudním postupem pro řešení sporů. To podporuje i fakt, že pro doručování písemností v průběhu ADR řízení pak mj. dostačuje doručení na elektronickou

${ }^{146}$ § 2 a násl. Zákon č. 300/2008 Sb., o elektronických úkonech a autorizované konverzi dokumentů, ve znění pozdějších předpisů (dále jen „ZEÚ“).

${ }^{147}$ Tyto informace byly částečně uvedeny v rámci panelové diskuze s tématem „Ochrana spotř̌ebitele: Jak bezpečně nakupovat na internetu?" konané dne 10. 5. 2016 na Právnické fakultě Masarykovy univerzity a dále nám byly poskytnuty zaměstnanci oddělení ADR ČOI.

${ }^{148}$ Důvodová zpráva. S. 43, 81, 83 nebo 85.

${ }^{149}$ V květnu 2016 bylo Českou poštou, jakožto správcem systému datových schránek, evidováno 83.689 datových schránek zřízených pro fyzické osoby a 118.640 datových schránek zř́izených pro podnikající fyzické osoby (jedná se o poslední veřejně dostupný údaj tohoto druhu). Právě tyto osoby pak mohou teoreticky využít svých datových schránek k zaslání návrhu. Vzhledem k tomu, že většina občanů České republiky může vystupovat v pozici spotřebitele, je ale celkový počet datových schránek nízký a jejich využívání tak nelze považovat za rozšǐřené. Aktuální počet datových stránek je uveden zde: Oficiální stránky Datových schránek [online]. Facebook [cit. 20. 3. 2017]. Dostupné z: https://cs-cz.facebook.com/DatoveSchranky/

${ }^{150}$ V roce 2013 došlo k vydání 271.779 kvalifikovaných certifikátů, v roce 2014 k vydání 277.977 kvalifikovaných certifikátů a v roce 2015 k vydání 287.385 kvalifikovaných certifikátů (od roku 2002 do roku 2015 došlo celkem k vydání 1.961 .723 kvalifikovaných certifikátů). Platnost certifikátu je vždy přibližně jednoroční (záleží na konkrétním poskytova teli). Každý rok pak dochází ke zneplatnění přibližně 8.000 certifikátů. Tyto informace nám byly poskytnuty Ministerstvem vnitra, odborem veřejné správy a eGovernmentu. 
adresu, kterou strany sdělily ČOI, tedy po zahájení sporu již požadavek využití uznávaného elektronického podpisu či datové schránky odpadá. ${ }^{152} \mathrm{Na}$ podnikatele pak požadavek komunikovat prostřednictvím datové schránky $v$ průběhu celého řešení sporů kladen není, i když ve valné většině bude vystupovat jako právnická osoba, ${ }^{153}$ které zákon ukládá povinnost datovou schránku zř́́dit. ${ }^{154}$

Na základě výše uvedených důvodů by tak $\mathrm{k}$ větší popularitě řešení spotřebitelských sporů mimosoudně přispělo, pokud by požadavek na nutnost doplnit elektronicky podaný návrh písemnou listinou, uznávaným elektronickým podpisem nebo samotný návrh zaslat datovou schránkou, odpadl. Dle našeho názoru by tak mělo zcela dostačovat $\mathrm{k}$ iniciaci sporu uvedení elektronické adresy (ostatně tak je tomu právě $\mathrm{v}$ př́ípadě zahájení sporu $s$ využitím ODR platformy), prostřednictvím které bude spotřebitel komunikovat, protože ten má zásadní zájem na vyřešení sporu. Lze sice argumentovat tím, že by mohlo dojít $\mathrm{k}$ navýšení sporů, které budou ze strany spotřebitele zjevně neopodstatněné (respektive neodůvodněné), ${ }^{155}$ nicméně na základě postavení a zkušeností ČOI (a dalších subjektů mimosoudního řešení sporů) by neměl být problém takové př́ipady snadno eliminovat.

Možnost podat návrh na zahájení sporu prostřednictvím online formuláře ADR poskytovaného ČOI ale nelze zaměňovat $s$ řízením zahájeným prostřednictvím ODR platformy. V případě, že spotřebitel zahájí přeshraniční spor prostřednictvím online formuláře ADR, ČOI se tímto návrhem i přesto může zabývat, shledá-li to jako vhodné. ${ }^{156} \mathrm{~V}$ př́ípadě, že se však takovýmto přeshraničním sporem nebude dále zabývat, doporučí spo-

${ }^{151}$ A to i díky jednotnému evropskému režimu pro elektronickou identifikaci na základě nařízení Evropského parlamentu a Rady (EU) č. 910/2014 ze dne 23. července 2014 o elektronické identifikaci a službách vytvářejících důvěru pro elektronické transakce na vnitřním trhu a o zrušení směrnice 1999/93/ES. In: EUR-Lex [právní informační systém]. Úřad pro publikace Evropské unie [cit. 20. 3. 2017]. Dostupné z: http://eurlex.europa.eu/legal-content/CS/TXT/?qid = 1465647841477\&uri = CELEX:32014R0910

${ }^{152} \S 20 \mathrm{v}$ ZOS a článek 14 pravidel ČOI.

153 Je rovněž více pravděpodobné, že právnická osoba bude disponovat uznávaným elektronickým podpisem.

154 § 5 . ZEÚ.

${ }^{155} \S$ 20q odst. 2 písm. d). ZOS.

156 Článek 15. Pravidla ČOI. 
třebiteli příslušné evropské spotřebitelské centrum v rámci sítě ECC-Net, které je kontaktním místem pro řešení sporů prostřednictvím ODR platformy, což ale neznamená, že jí k řešení sporu bude využito. ČOI se tak na základě pravidel stanovených pro mimosoudní řešení sporů zabývá všemi vnitrostátními spory a využívá k tomu i online formuláře ADR. Přestože nařízení o ODR nelimituje využívání ODR platformy jen na přeshraniční spory, ČOI ji jako subjekt mimosoudního řešení sporů nijak nevyužívá (v rámci pravidel ČOI na ni odkazuje jen v případě přeshraničního sporu) a rovněž nijak nedoporučuje. ${ }^{157}$

Řešení přeshraničních sporů českými spotřebiteli s využitím ODR platformy dle informací ČOI bylo prozatím využito minimálně, což dokládá neúspěch celého režimu. Hlavní problém shledáváme v obecné nedůvěře (ze strany ČOI) v ODR mechanismus zavedený Evropskou unií, jeho komplikovanosti a v dalších dílčích problémech.

ČAK, jako druhý ze subjektů mimosoudního řešení sporů aprobovaný Ministerstvem průmyslu a obchodu, k zahájení řešení sporu uvádí následující:

„Návrh lze podat písemně nebo elektronicky prostřednictvím formuláře uvedeného na internetových stránkách České advokátní komory podepsaný uznávaným elektronickým podpisem nebo zaslaný prostřednictvím datové schránky osoby, jež návrh podává. “158

V polovině roku 2016 ČAK evidoval celkově 3 návrhy podané spotřebitelem (klientem); u nich se ale nepodařilo dosáhnout dohody mezi stranami. ${ }^{159}$ Neúspěch tohoto režimu shledáváme nejen díky nutnosti v konkrétním případě zahájit řešení sporu výše popsaným způsobem, ale zejména díky tomu, že mechanismus řešení sporů nebyl v minulosti ČAK využívaný. ${ }^{160} \mathrm{~V}$ současné chvíli tak dle našeho názoru není mimosoudní řešení sporů v rámci ČAK málo populární ani tak kvůli formálním požadavkům pro podání návrhu či nemožnosti využít formuláře pro podání návrhu onli-

\footnotetext{
157 Článek 5 odst. 1 pravidel ČOI a článek 7 nařízení o ODR.

158 Článek I. odst. (4). Pravidla ČAK.

159 Tyto informace byly poskytnuty ČAK 1. 6. 2016. Ke zlepšení situace a ke zvýšení zájmu o dané řešení sporů prozatím v rámci tohoto subjektu nedošlo.
} 
$n e,{ }^{161}$ ale spíše proto, že daný způsob řešení sporů nemá v této oblasti tradici. $\mathrm{K}$ většímu využívání mimosoudního řešení sporů v rámci ČAK by pravděpodobně přispěla jeho větší propagace, ale zejména pak základní ověření, jestli si spotřebitel opravdu takovýto mechanismus vůbec žádá.

Nejnovějším subjektem mimosoudního řešení sporů aprobovaný Ministerstvem průmyslu a obchodu je SČS. K zahájení návrhu uvádí následující:

„Návrh lze podat písemně prostréednictvím formuláře vystaveného ke stažení na stránkách SČS http://www.konzument.cz/reseni-sporu/alternativni-zpusobyreseni/scs-a-mus.php nebo elektronicky prostrednictvím (on-line) formuláře $k$ dispozici tamtéż." ${ }^{162}$

Tento subjekt tedy sice nikterak neomezuje požadavky kladené na formu identifikace při podání návrhu, ${ }^{163}$ je nicméně faktem, že v současnosti elektronický formulář, prostřednictvím kterého by spotřebitel podal svoji stížnost online, ${ }^{164}$ není dostupný. ${ }^{165}$ Tento nehotový stav tedy zatím vyvolává nedůvěru a bude nutné tomuto poskytovateli ponechat ještě čas pro to, aby své mechanismy pro řešení spotřebitelských sporů dopracoval. Až v té chvíli tak bude možné detailněji zhodnotit úspěšnost mimosoudního řešení spotřebitelských sporů a možnost jejich řešení online tímto subjektem.

\footnotetext{
${ }^{160}$ Upozorňujeme ale na v minulosti zavedenou možnost vést smírčí řízení mezi spotřebitelem advokátem, které má za cíl eliminovat nedorozumění mezi účastníky. Extrakt usnesení představenstva České advokátní komory č. 2/1998 Věstníku ze dne 14. dubna 1998, kterým se upravuje smírčí řízení (advokátní smírčí řád), ve znění usnesení představenstva České advokátní komory č. 1/2003 Věstníku.

${ }^{161}$ ČAK plní požadavek stanovený § 20j písm. a) ZOS (provozuje „aktualizované internetové stránky, které [...] umožňuji podání návrhu na zahájení řešení sporu on-line [...]“) tak, že přímo odkazuje na možnost využití ODR platformy.

162 Článek 4 odst. 3. Pravidla SČS.

${ }^{163}$ Tyto požadavky nejsou pak omezeny ani na základě ZOS, jak je tomu $\mathrm{v}$ případě ČOI $\S 20 \mathrm{n}$ odst. 4 ZOS.

${ }^{164}$ SČS však na svých stránkách odkazuje na možnost řešit spory pomocí ODR platformy. Platforma EU pro mimosoudní urovnání sporů (ADR-MUS) on line [online]. Sdružení českých spotřebitelů [cit. 28. 3. 2017]. Dostupné z: http://www.konzument.cz/reseni-sporu/alternativni-zpusoby-reseni/platforma-on-line.php

${ }^{165}$ SČS a MUS [online]. Sdružení českých spotřebitelů [cit. 28. 3. 2017]. Dostupné z: http://www.konzument.cz/reseni-sporu/alternativni-zpusoby-reseni/scs-a-mus.php
} 


\section{ZÁVĚR}

V první části tohoto textu byl představen evropský právní režim alternativního řešení sporů online zakotvený na základě směrnice o spotřebitelském ADR a nařízení o ODR. Tento režim dopadá jen na subjekty alternativního řešení sporů; na jiné (neaprobované) poskytovatele ADR a ODR se nevztahuje. $\mathrm{V}$ další části pak byl charakterizován proces podání stížnosti prostřednictvím ODR platformy a analyzovány jednotlivé fáze řešení sporů. Tato část se tak snažila přehledně prezentovat jednotlivé kroky, které spotřebitel absolvuje, pokud se rozhodne využít ODR platformy $k$ dosažení řešení sporu. ODR platforma slouží pouze jako zprostředkovatel informací a významnou roli hraje zejména $\mathrm{v}$ počátečních fázích mimosoudního řešení, kdy shromažd’uje jednotlivá fakta týkající se konkrétního sporu mezi stranami. Nelze tedy jejím prostřednictvím spor rozhodnout, a tudíž neslouží jako poskytovatel online řešení sporů (což lze ale z jejího názvu zprvu předpokládat); slouží tak pouze jako kontaktní bod pro výměnu informací mezi stranami a při řešení sporu jim asistuje. Rozhodování o věci samé je vždy ponecháno jen na subjektech alternativního řešení sporů na základě směrnice o spotřebitelském ADR, vnitrostátních právních předpisů a pravidel samotného subjektu ADR. Postup pro úspěšné vyřešení sporu pomocí subjektu alternativního řešení sporů je poměrně dost komplikovaný a strany musí projít složitým procesem, ${ }^{166}$ pokud chtějí dosáhnout řešení sporu a vúvodu se vzájemně nedohodnou. Jelikož je pak celý režim dobrovolný, lze z důvodu jeho menší přehlednosti a celkové složitosti předpokládat, že zvolené řešení nebude př́liš úspěšné a bude často př̀erušeno ještě před jeho koncem. $\mathrm{K}$ tomu dále přispívá fakt, že výše popsaný režim mimosoudního řešení sporů online je úzce spjat se specifiky jednotlivých právních řádů členských států a nevyužívá tak efektivity, které ODR poskytuje $\mathrm{v}$ př́ípadě, kdy je pokud možno co nejméně spjato s právním řádem daného státu.

\footnotetext{
${ }^{166}$ To shledáváme v rozporu s recitálem 8 nařízení o ODR. „Řešení sporů on-line nabízí jednoduché, efektivní, rychlé a levné mimosoudní řešení sporů vzniklých $v$ souvislosti s transakcemi prováděnými on-line."
} 
Výše představená právní úprava tak zavádí další (alternativní) režim mimosoudního řešení sporů, než jaký fungoval v členských státech doposud. Mimosoudní řešení spotřebitelských sporů si již v minulosti vydobylo své postavení a zavedení dalšího (odlišného) souboru pravidel vede nikoli ke sjednocení, ale naopak $\mathrm{k}$ další fragmentaci a zejména pak ke zmatení spotřebitele, který se nemusí orientovat v tom, který z režimů má využít. ${ }^{167}$

$\mathrm{V}$ druhé části byly představeny dopady evropského právního režimu na českou právní úpravu. Evropský právní režim v České republice využívání mimosoudního řešení spotřebitelských sporů je upraven na základě § $20 \mathrm{~d}$ a násl. ZOS. Ten však dle uvedeného zásadním způsobem dané řešení nezpopularizoval (a to ani v online prostředí). Zejména ČOI tak spíše navázala na své zkušenosti a reputaci z minulosti. To ale nic nemění na faktu, že mimosoudní řešení sporů poskytované ČOI je stále poměrně úspěšné i přes to, že většina sporů je zahájena zasláním potvrzení poštou. Ke zvýšení popularity mimosoudního řešení sporů $\mathrm{v}$ online prostředí by nicméně $\mathrm{v}$ budoucnu mělo přispět zejména odstranění zbytečně formálního požadavku zakotveného v § 20n odst. 4 ZOS (na ostatní subjekty se tento požadavek nevztahuje, pokud si tak samy nestanoví, jak to učinila ČAK), tedy podmínka podat návrh prostřednictvím online formuláře ADR doplněný písemnou listinou, uznávaným elektronickým podpisem nebo samotný návrh zaslat datovou schránkou. $\mathrm{V}$ rámci mimosoudního řešení sporů poskytovaného ČAK nebyla efektivita a účelnost řešení specifického druhu sporů prozatím prokázána; řešení poskytované SČs je prozatím nehotové. Tyto skutečnosti by měly být př́íkladem pro případné další zájemce o poskytování mimosoudního řešení sporů zavedeného $\mathrm{v} Z \mathrm{ZOS}$, kdy by bylo vhodné nejprve zejména zhodnotit, jestli jsou takové mechanismy pro dané služby a tedy pro danou oblast potenciálních sporů vůbec žádané a jestli opravdu přinesou kýžené výhody. $\mathrm{V}$ takovém případě je pak nezbytné dané mechanismy

\footnotetext{
${ }^{167}$ Konkrétním problémům na evropské úrovni jsme se věnovali např. zde: LOUTOCKÝ, Pavel. Online Dispute Resolution to Resolve Consumer Disputes from the perspective of European Union Law: Is the Potential of ODR Fully Used? Masaryk University Journal of Law and Technology, Masarykova univerzita, 2016, roč. 10, č. 1, s. 113-127. ISSN 1802-5943 nebo LOUTOCKÝ, Pavel. Practical Impacts of the EU Regulation on Online Dispute Resolution for Consumer Disputes. In Klára Drličková, Tereza Kyselovská. COFOLA INTERNATIONAL 2016. Brno: Masaryk University, 2016. s. 254-268, 15 s. ISBN 978-80-210-8356-1.
} 
pro řešení sporů navrhnout a upravit s dưrazem na jednoduchost a uživatelskou přívětivost pro spotřebitele. V současnosti je totiž patrné, že konkrétní úprava řešení sporů poskytnutá uvedenými subjekty není příliš přívětivá a každý ze subjektů ji pojal odlišně. To dále nepřispívá $\mathrm{k}$ potřebné přehlednosti poskytnutého řešení.

Závěrem je však nutno konstatovat, že je obtížné nabídnout komplexní nápravu celého současného evropského režimu mimosoudního řešení spotřebitelských sporů využívajícího moderních technologií. ODR prokazuje svou efektivitu zejména, když je úzce napojeno na konkrétní definiční autoritu, což se ale v př́ipadě evropské právní úpravy neděje. Vhodnější by bylo, kdyby se Evropská unie $\mathrm{k}$ úpravě dané problematiky postavila zcela jiným způsobem a nedošlo tak jejímu roztřiššění. Pro úpravu problematiky online řešení spotřebitelských sporů bychom za mnohem vhodnější považovali, kdyby Evropská unie poskytla $\mathrm{v}$ daném př́ípadě uzavřený online systém, který by byl výhradně zaměřen na spory vzniklé z elektronického obchodování. Tím máme na mysli zejména to, že by ODR platforma nefungovala jen jako zprostředkovatel informací, ale opravdu (jak název evokuje) by poskytovala i rozhodování samotného sporu. ODR platforma by tak poskytovala nejen prostor pro podání stížnosti, ale rovněž by ji sama řešila. Poskytovala by tak kompletní zajištění pro celé mimosoudní řešení sporů online a vystupovala by jako jediná a unifikovaná autorita pro řešení online sporů v oblasti elektronického obchodování (což by posléze nemuselo bránit rozšíření i na oblasti jiné). Právě v takovém případě by měl být systém řešení online sporů pro spotřebitele přehledný a ODR platforma by zejména spotřebiteli poskytovala komplexní nástroj. Ten by tak $\mathrm{v}$ rámci rozhodování sporu nemusel využívat jednotlivých subjektů ADR, nemusel by trpět rozdílnosti jednotlivých subjektů $\mathrm{ADR}$ a případně právních řádů členských států. Právě v takovém př́padě se tak bude jednat o jednoduché a dostupné řešení, které není přes míru komplikované a matoucí. 


\section{PŘÍLOHA Č. 1: OBRÁZKOVÁ PŘÍLOHA}

\begin{tabular}{|c|c|c|c|c|c|c|}
\hline \multirow{3}{*}{$\begin{array}{l}\text { ONLINE } \\
\text { DISPƯTE } \\
\text { RESOLUTION }\end{array}$} & BG & български & cs & ceseština & DA & Dansk \\
\hline & DE & Deutsch & ET & eesti & EL & EMnquiká \\
\hline & EN & English & ES & Español & FR & français \\
\hline \multirow{5}{*}{$\begin{array}{l}\text { European } \\
\text { Commission } \\
\text { official website } \\
\text { The Online Dispute Resolution website } \\
\text { is an official website managed by the } \\
\text { European Commission dedicated to } \\
\text { helping consumers and traders resolve } \\
\text { their disputes out-of-court. }\end{array}$} & HR & hrvatski & & italiano & LT & lietuviu \\
\hline & LV & latviešu & HU & magyar & MT & il-Malti \\
\hline & NL & Nederlands & & polski & PT & português \\
\hline & Ro & română & sk & slovenčina & $\mathrm{SL}$ & slovenščina \\
\hline & FI & suomi & sv & Svenska & & \\
\hline
\end{tabular}

Obrázek č. 2: Výběr jazyka

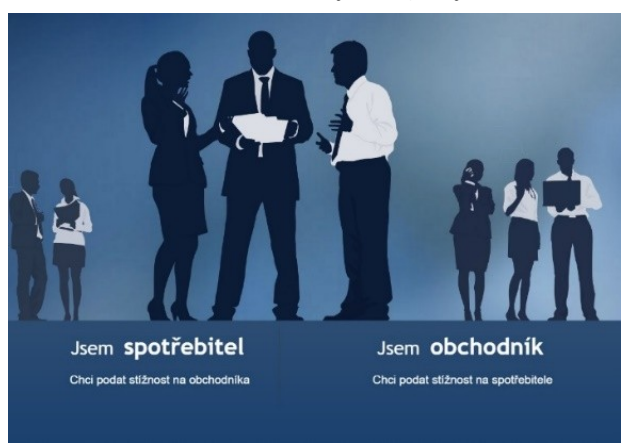

Obrázek č. 3: Podání stížnosti

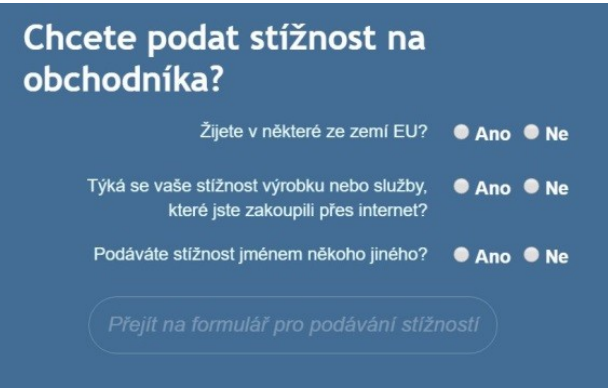

Obrázek č. 4: Vyplnění základních informací 


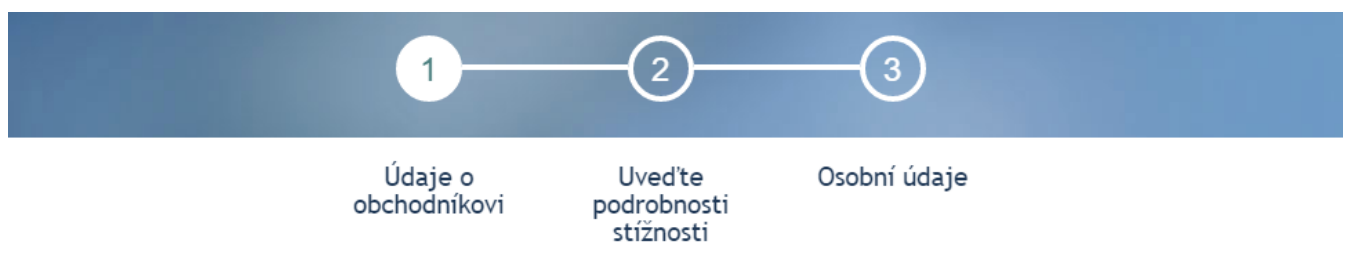

V naši databázi múžete obchodniky vyhledávat podle jména/názvu nebo podle adresy jejich internetových stránek. Pokud máme na obchodnika v databázi kontakt, údaje se do políček niže doplní automaticky.

Pokud ne, zadejte údaje sami.

Adresa obchodnika: $\begin{array}{lll}\text { Ulice } \\ \text { Ulice } \\ \qquad S C \check{c} & \text { Mẻsto } \\ \text { PSČsto } & \text { Mësto }\end{array}$

Obrázek č. 5: Údaje o obchodníkovi 

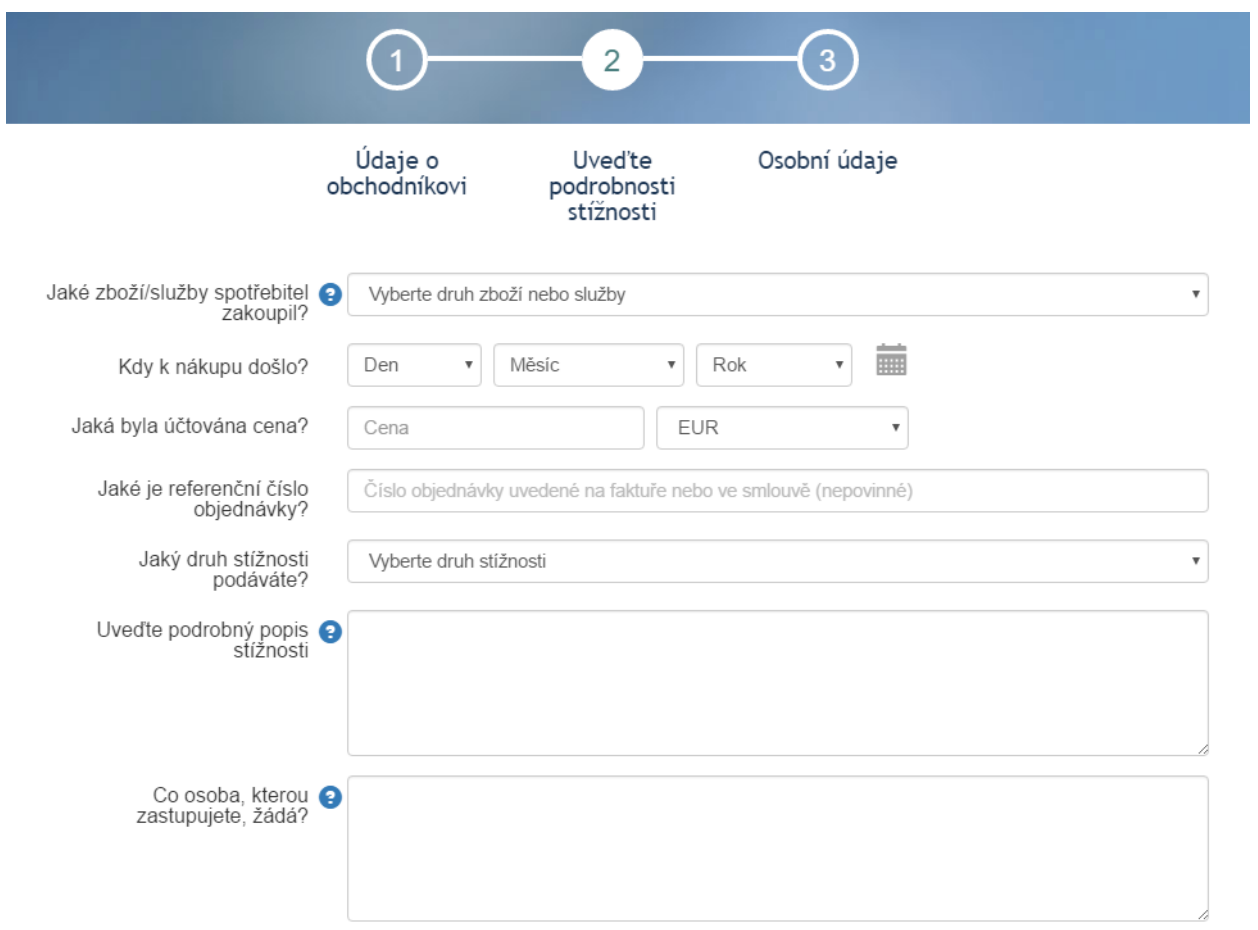

Chcete ke stižnosti připojit nějaké podklady? (nepovinné)

Kontaktoval již někdo obchodnika ohledně stižnosti? $\bigcirc \mathrm{Ano}$

Snažili jste se v dané věci dosáhnout mimosoudního $\bigcirc$ Ano $\bigcirc \mathrm{Ne}$ vyrovnání nebo jste ohledně stižnosti podali na druhou stranu žalobu u soudu?

Chce obchodnik věc postoupit konkrétnímu subjektu pro řešení sporủ?

\section{Obrázek č. 6: Podrobnosti stížnosti}




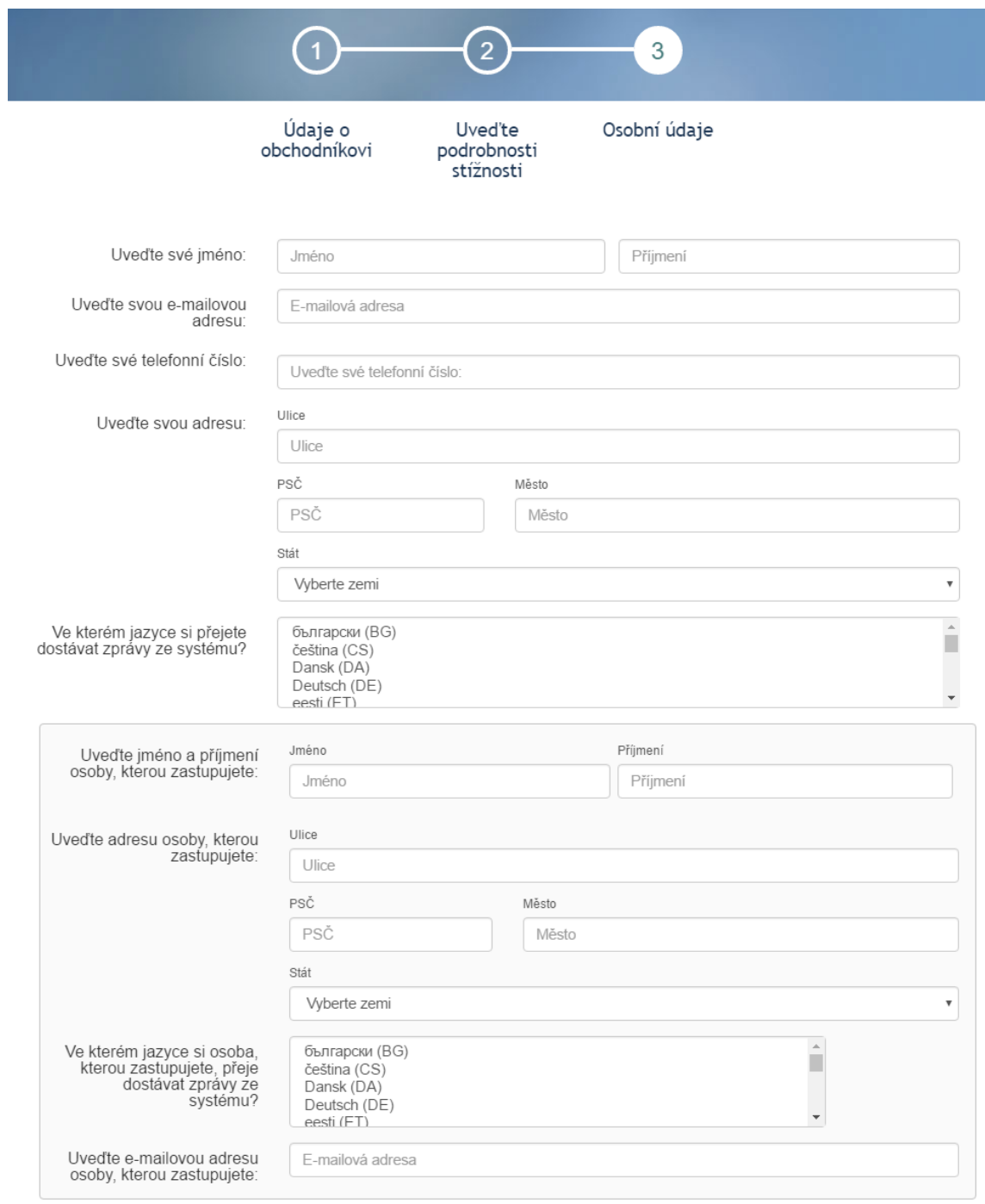

\section{Co bude následovat?}




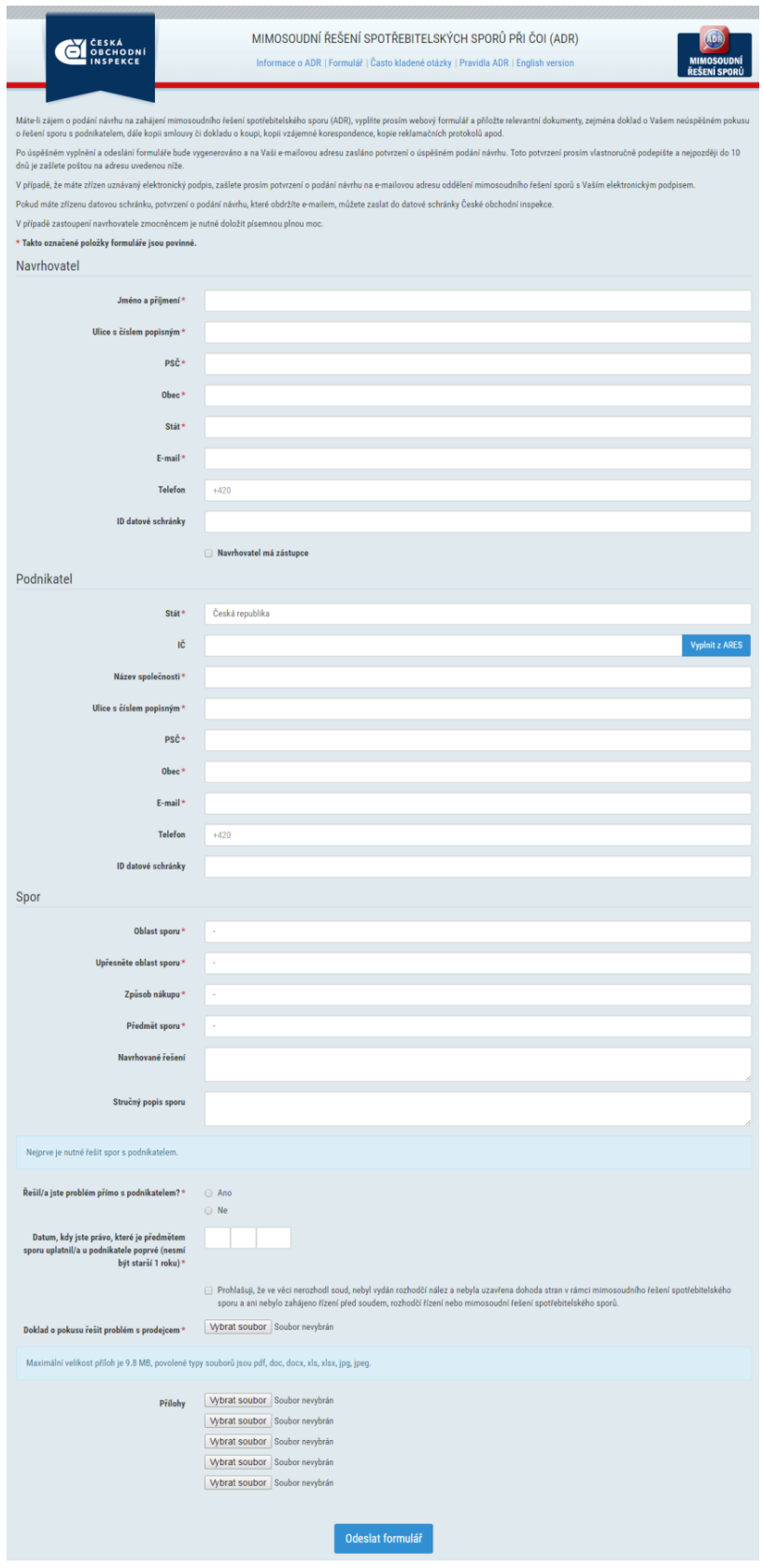

Obrázek č. 8: Online formulář ADR - Česká obchodní inspekce 


\section{SEZNAM LITERATURY A DALŠÍCH POUŽITÝCH ZDROJŮ}

\subsection{PRÁVNÍ PŘEDPISY}

[1] Nařízení Evropského parlamentu a Rady (ES) č. 861/2007 ze dne 11. července 2007, kterým se zavádí evropské řízení o drobných nárocích. In: EUR-Lex [právní informační systém]. Úřad pro publikace Evropské unie [cit. 29. 3. 2017]. Dostupné z: http://eurlex.europa.eu/legal-content/CS/TXT/?uri = CELEX\%3A32007R0861

[2] Nařízení Evropského parlamentu a Rady (EU) č. 524/2013 ze dne 21. května 2013 o řešení spotřebitelských sporů on-line a o změně nařízení (ES) č. 2006/2004 a směrnice 2009/22/ES (nařízení o řešení spotřebitelských sporů on-line). In: EUR-Lex [právní informační systém]. Úřad pro publikace Evropské unie [cit. 18. 3. 2017]. Dostupné z: http://eur-lex.europa.eu/legal-content/CS/TXT/?uri = celex:32013R0524

[3] Nařízení Evropského parlamentu a Rady (EU) č. 910/2014 ze dne 23. července 2014 o elektronické identifikaci a službách vytvářejících důvěru pro elektronické transakce na vnitřním trhu a o zrušení směrnice 1999/93/ES. In: EUR-Lex [právní informační systém]. Úřad pro publikace Evropské unie [cit. 20. 3. 2017]. Dostupné z: http://eur-lex.europa.eu/legalcontent/CS/TXT/?qid = 1465647841477\&uri = CELEX:32014R0910

[4] Prováděcí nařízení Komise (EU) 2015/1051 ze dne 1. července 2015 o způsobech provádění funkcí platformy pro řešení sporů on-line, o podrobnostech týkajících se elektronického formuláře pro podávání stížností a o pravidlech týkajících se spolupráce mezi kontaktními místy uvedených v nařízení Evropského parlamentu a Rady (EU) č. 524/2013 o řešení spotřebitelských sporů on-line. In: EUR-Lex [právní informační systém]. Úřad pro publikace Evropské unie [cit. 22. 3. 2017]. Dostupné z: http://eur-lex.europa.eu/legal-content/CS/TXT/? qid $=1463836823937 \&$ uri $=$ CELEX\%3A32015R1051

[5] Směrnice Evropského parlamentu a Rady 2000/31/ES ze dne 8. června 2000 o některých právních aspektech služeb informační společnosti, zejména elektronického obchodu, na vnitřním trhu (směrnice eo lektronickém obchodu). In: EUR-Lex [právní informační systém]. Úřad pro publikace Evropské unie [cit. 24. 3. 2017]. Dostupné z: http://eurlex.europa.eu/legal-content/CS/TXT/?qid=1463124717882\&uri=CELEX:32000L0031

[6] Směrnice Evropského parlamentu a Rady 2008/52/ES ze dne 21. května 2008 o některých aspektech mediace v občanských a obchodních věcech. In: EUR-Lex [právní informační systém]. Úřad pro publikace Evropské unie [cit. 13. 3. 2017]. Dostupné z: http://eur-lex.europa.eu/legal-content/CS/TXT/?qid = 1463132713289\&uri = CELEX:32008L0052

[7] Směrnice Evropského parlamentu a Rady 2013/11/EU ze dne 21. května 2013 o alternativním řešení spotřebitelských sporů a o změně nařízení (ES) č. 2006/2004 a směrnice 2009/22/ES (směrnice o alternativním řešení spotřebitelských sporů). In: EUR-Lex [právní informační systém]. Úřad pro publikace Evropské unie [cit. 24. 3. 2017]. Dostupné z: http://eur-lex.europa.eu/legal-content/CS/ALL/?uri = CELEX:32013L0011 
[8] Směrnice Evropského parlamentu a Rady 95/46/ES ze dne 24. října 1995 o ochraně fyzických osob v souvislosti se zpracováním osobních údajů a o volném pohybu těchto údajů. In: EUR-Lex [právní informační systém]. Úřad pro publikace Evropské unie [cit. 22. 3. 2017]. Dostupné z: http://eur-lex.europa.eu/legal-content/CS/TXT/?qid = 1463927078970\&uri =CELEX:31995L0046

[9] Směrnice Rady 93/13/EHS ze dne 5. dubna 1993 o nepřiměřených podmínkách ve spotřebitelských smlouvách. In: EUR-Lex [právní informační systém]. Úřad pro publikace Evropské unie [cit. 22. 3. 2017]. Dostupné z: http://eur-lex.europa.eu/legal-content/CS/TXT/? qid $=$ 1464014662319\&uri $=$ CELEX:31993L0013

[10] Zákon č. 127/2005 Sb., o elektronických komunikacích a o změně některých souvisejících zákonů (zákon o elektronických komunikacích), ve znění pozdějších předpisů.

[11] Zákon č. 202/2012 Sb., o mediaci a změně některých zákonů (zákon o mediaci), ve znění pozdějších předpisů.

[12] Zákon č. 216/1994 Sb., rozhodčím řízení o výkonu rozhodčích nálezů, ve znění pozdějších předpisů.

[13] Zákon č. 229/2002 Sb., o finančním arbitrovi, ve znění pozdějších předpisů.

[14] Zákon č. 300/2008 Sb., o elektronických úkonech a autorizované konverzi dokumentů, ve znění pozdějších předpisů.

[15] Zákon č. 458/2000 Sb., o podmínkách podnikání a o výkonu státní správy v energetických odvětvích a o změně některých zákonů (energetický zákon), ve znění pozdějších předpisů.

[16] Zákon č. 500/2004 Sb., správní řád, ve znění pozdějších předpisů

[17] Zákon č. 634/1992 Sb., zákon o ochraně spotřebitele, ve znění pozdějších předpisů.

[18] Zákon č. 99/1963 Sb., občanský soudní řád, ve znění pozdějších předpisů.

[19] Zákon č. 89/2012 Sb., občanský zákoník, ve znění pozdějších předpisů.

\subsection{JUDIKATURA}

[20] Rozsudek Soudního dvora (prvního senátu) ze dne 26. ř́jna 2006. Elisa María Mostaza Claro proti Centro Móvil Milenium SL. Věc C-168/05. In: Sbírka rozhodnutí. 2006, s. I-10421.

[21] Rozsudek Soudního dvora (čtvrtého senátu) ze dne 12. února 2009. Vereniging Noordelijke Land- en Tuinbouw Organisatie proti Staatssecretaris van Financiën, Věc C-515/07. In: Sbírka rozhodnutí. 2009, s. I-00839.

[22] Rozsudek Soudního dvora (prvního senátu) ze dne 6. ř́ijna 2009. Asturcom Telecomunicaciones SL proti Cristina Rodríguez Nogueira. Věc C-40/08. In: Sbírka rozhodnutí. 2009, s. I09579. 


\subsection{MONOGRAFIE}

[23] CORTÉS, Pablo. European Union's initiatives on ADR and ODR. Computer and Telecommunications Law Review, London: Sweet \& Maxwell, 2015, roč. 21, č. 8, 2015, s. 257-266. ISSN 13573128.

[24] CORTÉS, Pablo. Online Dispute Resolution for Consumers in the European Union. Oxon: Routldge, 2011, 288 s. ISBN 9780415562072.

[25] HODGES, Christopher J., Iris BENÖHR a Naomi CREUTZFELDT-BANDA. Consumer ADR in Europe: Civil Justice Systems. Oxford: Hart publishing, 2012, 503 s. ISBN 9781849463485.

[26] HÖRNLE, Julia. Cross - border Internet Dispute Resolution. Cambridge: Cambridge University Press, 2009, 320 s. ISBN 9780521896207.

[27] POLČÁK, Radim. Internet a proměny práva. 1. vyd. Praha: Auditorium, 2012, 388 s. edice Téma. ISBN 9788087284223.

[28] WEATHERILL, Stephen. EU Consumer Law and Policy. 2. vyd. B.m.: Edward Elgar Publishing, 2013, 253 s. ISBN 9780857936981. S. 25 a násl., nebo CORTÉS, Pablo. Online Dispute Resolution for Consumers in the European Union. Oxon: Routldge, 2011, 288 s. ISBN 9780415562072.

\section{4 ČASOPISECKÉ ZDROJE}

[29] BOGDAN, Michael. The New EU Regulation on Online Resolution for Consumer Disputes. Masaryk University Journal for Law and Technology, roč. 9, č. 1, 2015, s. 155-163. ISSN 18025943.

[30] CORTÉS, Pablo, Arno R. LODDER. Consumer Dispute Resolution Goes Online: Reflections on the Evolution of European Law for Out-of-Court Redress. Maastricht Journal of European and Comparative Law, 2014, roč. 21, č. 1, s. 14-38. ISSN 1023263X.

[31] CORTÉS, Pablo, Esteban DE LA ROSA. Building a global redress system for low-value cross-border disputes. International \& Comparative Law quaterly, Cambridge: Cambridge University Press, 2013, roč. 62, č. 2, s. 407-440. ISSN 00205893.

[32] CORTÉS, Pablo. A New Regulatory Framework for Extra-judicial Consumer Redress: Where We Are and How to Move Forward. Legal Studies, 2015, roč. 35, č. 1, s. 114-141. ISSN 1748-121X.

[33] CORTÉS, Pablo. European Union's initiatives on ADR and ODR. Computer and Telecommunications Law Review, London: Sweet \& Maxwell, 2015, roč. 21, č. 8, 2015, s. 257-266. ISSN 13573128.

[34] CORTÉS, Pablo. The impact of EU law in the ADR landscape in Italy, Spain and the UK: time for change or missed opportunity? ERA Forum, Berlin, Heidelberg: Springer Berlin Heidelberg, 2015, roč. 16, č. 2, s. 125-147. ISSN 18639038.

[35] GERTNER, Lucie. Mediace on-line v kontextu zákona o mediaci. Bulletin advokacie, Praha: Česká advokátní komora, 2013, roč. 6/2004, s. 41. ISSN 12106348. 
[36] HÖRNLE, Julia. Encouraging Online Dispute Resolution in the EU and Beyond-Keeping Costs Low or Standards High? European Law Review, London: Sweet \& Maxwell, 2013, roč. 38, s. 187-208. ISSN 03075400 .

[37] LOUTOCKÝ, Pavel. Online Dispute Resolution to Resolve Consumer Disputes from the perspective of European Union Law: Is the Potential of ODR Fully Used? Masaryk University Journal of Law and Technology, Masarykova univerzita, 2016, roč. 10, č. 1, s. 113-127. ISSN 1802-5943.

[38] LOUTOCKÝ, Pavel. Practical Impacts of the EU Regulation on Online Dispute Resolution for Consumer Disputes. In Klára Drličková, Tereza Kyselovská. COFOLA INTERNATIONAL 2016. Brno: Masaryk University, 2016. s. 254-268, 15 s. ISBN 978-80-210-8356-1.

[39] LOUTOCKÝ, Pavel. Slabiny a silné stránky online rozhodčího řízení se zaměřením na B2B transakce. Revue pro právo a technologie, Brno: Masarykova univerzita, 2012, roč. 3, č. 6 , s. 76-111. ISSN 18045383. S. 80-81.

[40] POBLET, Marta, Graham ROSS. ODR in Europe. In: WAHAB, Mohamed S. Abdel, Ethan KATSH, Daniel RAINEY. Online Dispute Resolution: Theory and Practice: A Treatise on Technology and Dispute Resolution. The Hague: Eleven International Publishing, 2012, s. 453-471. ISBN 9789490947255 .

\subsection{OSTATNÍ ZDROJE}

[41] ALLEWELDT, Frank, Senda KARA, Nicholas MCSPEDDEN-BROWN, Anna FIELDER, Fabian ZULEEG a Agathe OSINSKI. Contribution of the Internal Market and Consumer Protection to Growth. Directorate General for Internal Policies Policy Department A: Economic and Scientific Policy [online]. IP/A/IMCO/2014-04, prosinec 2014 [cit. 27. 3. 2017]. Dostupné z: http://www.europarl.europa.eu/RegData/etudes/STUD/2014/518762/IPOL_STU(2014)51876 2_EN.pdf

[42] Alternative Dispute Resolution (ADR) [online]. Chartered Trading Standards Insitiute [cit. 14. 3. 2017]. Dostupné z: http://www.tradingstandards.uk/advice/AlternativeDisputeResolution.cfm

[43] Analýza úpravy alternativních řšení sporů v jiných státech Evropské unie a judikatura soudů České republiky [online]. „Alternative Dispute Resolution“ (ADR) v Evropské unii a v České republice. Nejvyšší soud, úsek místopředsedy NS, oddělení evidence judikatury, 19. května 2014 [cit. 25. 3. 2017]. Dostupné z: http://www.nsoud.cz/JudikaturaNS_new/ns_web.nsf/ 0/86b6869e71f6e147c1257f6c00530d32/\$FILE/Alternative\%20Dispute\%20Resolution_ ADR.pdf

[44] Arbitration Fairness Act of 2015, která by danou možnost měla znemožnit. Arbitration Fairness Act of 2015. S.1133 - 114th Congress [online]. The United States Congress [cit. 23. 3. 2017]. Dostupné z: https://www.congress.gov/bill/114th-congress/senate-bill/1133 
[45] COLE, Tony, Ilias BANTEKAS, Federico FERRETTI, Christine RIEFA, Barbara WARWAS a Pietro ORTOLANI. Legal Instruments and Practice of Arbitration in the EU, Study [online]. Directorate General for Internal Policies Policy Department C: Citizens' Rights and Constitutional Affairs, 2014 [cit. 23. 3. 2017]. Dostupné z: http://www.europarl.europa.eu/ RegData/etudes/STUD/2015/509988/IPOL_STU(2015)509988_EN.pdf

[46] Commission Green Paper of 16 November 1993 on access of consumers to justice and the settlement of consumer disputes in the single market. In: EUR-Lex [právní informační systém]. Úřad pro publikace Evropské unie [cit. 13. 3. 2017]. Dostupné z: http://eur-lex.europa.eu/legal-content/EN/TXT/HTML/?uri = URISERV:132023\&from $=$ CS

[47] Commission Recommendation of 30 March 1998 on the principles applicable to the bodies responsible for out-of-court settlement of consumer disputes (Text with EEA relevance) (98/257/EC). In: EUR-Lex [právní informační systém]. Úřad pro publikace Evropské unie [cit. 27. 3. 2017]. Dostupné z: http://eur-lex.europa.eu/legal-content/EN/TXT/HTML/?uri=CELEX:31998H0257\&from $=$ CS

[48] Commission Recommendation of 4 April 2001 on the principles for out-of-court bodies involved in the consensual resolution of consumer disputes (notified under document number C(2001) 1016) (Text with EEA relevance) (2001/310/EC). In: EUR-Lex [právní informační systém]. Úřad pro publikace Evropské unie [cit. 27. 3. 2017]. Dostupné z: http://eur-lex.europa.eu/LexUriServ/LexUriServ.do?uri = CELEX:32001H0310:EN:HTML

[49] Consumer attitudes towards cross-border trade and consumer protection. Conducted by TNS Political \& Social at the request of the European Commission, Directorate-General for Health and Consumers [online]. European Commission. Public Opinion. Flash Eurobarometer 397. September 2015 [cit. 27. 3. 2017]. Dostupné z: http://ec.europa.eu/COMMFrontOffice/PublicOpinion/index.cfm/Survey/getSurveyDetail/instruments/FLASH/surveyKy/2031

[50] CORTÉS, Pablo. Enforcing EU Consumer Policy through Different Layers: Combining the Judicial and the Out-of-Court Mechanisms [online]. University of Leicester School of Law Research Paper No. 14-27, 2014 [cit. 22. 3. 2017]. Dostupné z: http://papers.ssrn.com/sol3/papers.cfm?abstract_id =2520487. S 4, 8-9.

[51] CREUTZFELDT, Naomi J. Implementation of the Consumer ADR Directive [online]. Prijato k publikaci v Journal of European Consumer and Market Law, no. 1-2016 [cit. 24. 3. 2017]. Dostupné z: http://ssrn.com/abstract $=2729208$

[52] Důvodová zpráva k zákonu č. 378/2015 Sb., kterým se mění zákon č. 634/1992 Sb., o ochraně spotřebitele, ve znění pozdějších předpisů, a některé další zákony. Sněmovní tisk 445/0, část č. 1/16 [online]. Poslanecká sněmovna Parlamentu České republiky [cit. 29. 3. 2017). Dostupné z: https://www.psp.cz/sqw/text/tiskt.sqw?O $=7 \& \mathrm{CT}=445 \& \mathrm{CT} 1=0$

[53] ECODIR [online]. Electronic Consumer Dispute Resolution [cit. 22. 3. 2017]. Dostupný z: http://www.ecodir.org/

[54] European Consumers Centres [online]. European Comission [cit. 22. 3. 2017]. Dostupné z: http://ec.europa.eu/consumers/solving_consumer_disputes/non-judicial_redress/ecc-net/index_en.htm 
[55] Extrakt usnesení představenstva České advokátní komory č. 2/1998 Věstníku ze dne 14. dubna 1998, kterým se upravuje smírčí řízení (advokátní smírčí řád), ve znění usnesení představenstva České advokátní komory č. 1/2003 Věstníku.

[56] Formulár̆ návrhu na zahájení ř́zení o mimosoudním řešení spotřebitelského sporu (ADR) [online]. Česká obchodní inspekce [cit. 28. 3. 2017]. Dostupné z: https://adr.coi.cz/cs/form

[57] Impact Assessment on Proposal for a Directive of the European Parliament and of the Council on Alternative Dispute Resolution for consumer disputes (Directive on consumer ADR) and Proposal for Regulation of the European Parliament and of the Council on Online Dispute Resolution for consumer disputes (Regulation on consumer ODR) [online]. SEC(2011) 1408 final [cit. 27. 3. 2017]. Dostupné z: http://ec.europa.eu/consumers/archive/redress_cons/docs/impact_assessment _adr_en.pdf

[58] Jak zahájit spor? - Úvod [online]. Aukro [cit. 28. 3. 2017]. Dostupné z: http://aukro.cz/country_pages/56/0/education/guide_debate/index.php

[59] KRAMER, Xandra E. A European Perspective on E-Justice and New Procedural Models: Transforming the Face of Cross-Border Civil Litigation and Adjudication in the EU [online]. Working paper (2015), November 1, 2015 [cit. 27. 3. 2017]. Dostupné z: http://papers.ssrn.com/sol3/papers.cfm?abstract_id $=2696978$

[60] LOUTOCKÝ, Pavel. Mimosoudní řešení spotřebitelských sporů online v právu EU [online]. Brno, 2017 [cit. 27. 3. 2017]. Rigorózní práce. Masarykova univerzita, Právnická fakulta. Dostupné z: https://is.muni.cz/auth/th/210290/pravf_r_Rigorozni_prace_Pavel_Loutocky.pdf

[61] Mimosoudní řešení sporů (ADR) [online]. Evropské spotřebitelské centrum Česká republika [cit. 28. 3. 2017]. Dostupné z: http://www.evropskyspotrebitel.cz/mimosoudni-resenisporu-adr/mimosoudni-reseni-sporu-adr-63164

[62] Obratte se na vnitrostátní kontaktní místo [online]. Řešení sporů online [cit. 22. 3. 2017]. Dostupné z: https://webgate.ec.europa.eu/odr/main/?event = main.complaints.odrList

[63] Oficiální stránky Datových schránek [online]. Facebook [cit. 20. 3. 2017]. Dostupné z: https://cs-cz.facebook.com/DatoveSchranky/

[64] Online dispute resolution for cross-border electronic commerce transactions: draft procedural rules [online]. Working Group III (Online Dispute Resolution). United Nations Commission on International Trade Law (UCITRAL). Thirty - first session. New York, 9-13 February 2015, A/CN.9/WG.III/WP.133 [cit. 22. 3. 2017]. Dostupné z: https://documents-ddsny.un.org/doc/UNDOC/LTD/V14/080/65/PDF/V1408065.pdf?OpenElement

[65] Platforma EU pro mimosoudní urovnání sporů (ADR-MUS) on line [online]. Sdružení českých spotřebitelů [cit. 28. 3. 2017]. Dostupné z: http://www.konzument.cz/reseni-sporu/alternativni-zpusoby-reseni/platforma-on-line.php

[66] Pravidla pro postup pověřeného subjektu (České advokátní komory) při mimosoudním řešení spotřebitelských sporů [online]. Česká advokátní komora [cit. 28. 3. 2017]. Dostupné z: http://www.cak.cz/assets/pravidla-pro-postup-pri-msrss.pdf 
[67] Pravidla pro postup pověřeného subjektu Sdružení českých spotřebitelů při mimosoudním řešení spotřebitelských sporů [online]. Sdružení českých spotřebitelů [cit. 28. 3. 2017]. Dostupné z: http://www.konzument.cz/users/files/reseni-sporu/SCS-proces-pravidla-MUS-2.pdf

[68] Pravidla pro postup při Mimosoudním řešení spotřebitelských sporů (ADR) [online]. Česká obchodní inspekce [cit. 29. 3. 2017]. Dostupné z: http://www.coi.cz/userdata/files/dokumenty-ke-stazeni/pravidla-pro-postup-adr.pdf

[69] Report on „European judicial systems - Edition 2014 (2012 data): efficiency and quality of justice" [online]. Council of Europe [cit. 27. 3. 2017]. Dostupné z: http://www.coe.int/t/dghl/cooperation/cepej/evaluation/2014/Rapport_2014_en.pdf

[70] SČS a MUS [online]. Sdružení českých spotřebitelů [cit. 28. 3. 2017]. Dostupné z: http://www.konzument.cz/reseni-sporu/alternativni-zpusoby-reseni/scs-a-mus.php

[71] Seznam subjektů mimosoudního řešení spotřebitelských sporů [online]. Ministerstvo průmyslu a obchodu [cit. 29. 3. 2017]. Dostupné z: http://www.mpo.cz/dokument171389.html

[72] Solving disputes online: New platform for consumers and traders [online]. European Commission - Press release [cit. 24. 3. 2017]. Dostupné z: http://europa.eu/rapid/press-release_IP16-297_en.htm

[73] Úvodní stránka - řě̌ení sporů online [online]. Evropská komise [cit. 27. 3. 2017]. Dostupné z: https://webgate.ec.europa.eu/odr/

\section{ZDROJE OBRÁZKŮ}

\section{Obrázek č. 2: Výběr jazyka}

[74] Online dispute resolution [online]. Řešení sporů online [cit. 29. 3. 2017]. Dostupné z: https://webgate.ec.europa.eu/odr

\section{Obrázek č. 3: Podání stížnosti}

[75] Úvodní stránka - Ǩešení sporů online [online]. Řešení sporů online [cit. 29. 3. 2017]. Dostupné z: https://webgate.ec.europa.eu/odr/main/index.cfm?event=main.home.show $\& \ln g=\mathrm{CS}$

\section{Obrázek č. 4: Vyplnění základních informací}

[76] Úvodní stránka - Řešení sporů online [online]. Řešení sporů online [cit. 29. 3. 2017]. Dostupné z: https://webgate.ec.europa.eu/odr/main/index.cfm?event=main.home.show \&lng $=\mathrm{CS}$

\section{Obrázek č. 5: Údaje o obchodníkovi}

[77] Údaje o obchodníkovi [online]. Řešení sporů online [cit. 29. 3. 2017]. Dostupné z: https://webgate.ec.europa.eu/odr/main/index.cfm?consumer-question $1=$ Y\&consumer-question $2=\mathrm{Y} \&$ consumer-question $3=\mathrm{Y} \&$ complaintType $=3 \&$ event $=$ main. complaints.new 


\section{Obrázek č. 6: Podrobnosti stížnosti}

[78] Podrobnosti stížnosti [online]. Řešení sporů online [cit. 29. 3. 2017]. Dostupné z: https://webgate.ec.europa.eu/odr/main/index.cfm?consumer-question1 $=$ Y\&consumer-question $2=\mathrm{Y} \&$ consumer-question $3=\mathrm{Y} \&$ complaint Type $=3$ \&event $=$ main. complaints.new

\section{Obrázek č. 7: Osobní údaje}

[79] Osobní údaje [online]. Řešení sporů online [cit. 29. 3. 2017]. Dostupné z: https://webgate.ec.europa.eu/odr/main/index.cfm?consumer-question $1=$ Y\&consumer-question2 = Y\&consumer-question $3=$ Y\&complaintType $=3$ \&event $=$ main.complaints.new

\section{Obrázek č. 8: Online formulář ADR - Česká obchodní inspekce}

[80] Formulár̆ návrhu na zahájení ř́zení o mimosoudním řešení spotřebitelského sporu (ADR) [online]. Česká obchodní inspekce [cit. 29. 3. 2017]. Dostupné z: https://adr.coi.cz/cs/form

Toto dílo lze užít v souladu s licenčními podmínkami Creative Commons BY-SA 4.0 International (http://creativecommons.org/licenses/by-sa/4.0/legalcode). 
